

\section{Diktat \\ Pengantar Ilmu Hukum}

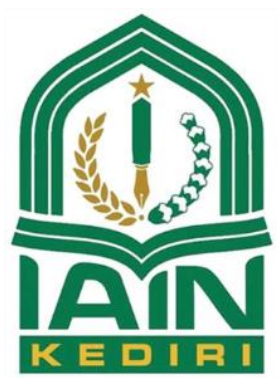

Oleh:

Ach. Khiarul Waro Wardani

Hutrin Kamil

Moch Choirul Rizal

Fakultas Syariah

Institut Agama Islam Negeri (IAIN) Kediri

2021 
Diktat

Pengantar Ilmu Hukum

Penyusun

Ach. Khiarul Waro Wardani

Hutrin Kamil

Moch Choirul Rizal

Penyunting

Moch Choirul Rizal

Penata Letak dan Desain Sampul

Moch Choirul Rizal

(Gambar pada sampul diunduh dari https://greatblogabout.org/introductionto-law-ppt/ dan diolah seperlunya)

Terbit pertama kali dalam bahasa Indonesia, di Kota Kediri, Oktober 2021, vii + 81 halaman, $15 \times 23 \mathrm{~cm}$,

Diterbitkan oleh:

Fakultas Syariah

Institut Agama Islam Negeri (IAIN) Kediri 



\section{KATA PENGANTAR}

Alhamdulillah, puji syukur senantiasa kami panjatkan kehadirat Allah SWT atas segala nikmat yang diberikan, sehingga kami dapat menyusun "Diktat Pengantar Ilmu Hukum" yang sederhana ini. Salawat serta salam tidak lupa kami haturkan kepada Nabi Muhammad SAW.

Diktat ini kami maksudkan untuk menambah referensi bagi mahasiswa pada Fakultas Syariah Institut Agama Islam Negeri (IAIN) Kediri yang mengambil mata kuliah "Pengantar Ilmu Hukum". Penyusunan diktat ini kami selaraskan dengan rencana pembelajaran semester dalam mata kuliah yang dimaksud.

Diktat ini kami susun berdasarkan pada berbagai referensi terkait dasar-dasar ilmu hukum yang terbit sebelumnya. Untuk mempermudah pembacaan, diktat ini tersusun atas 10 (sepuluh) bab: (1) Bab I: Karakteristik Ilmu Hukum; (2) Bab II: Pengertian, Fungsi, dan Tujuan Hukum; (3) Bab III: Hukum sebagai Institusi Sosial; (4) Bab IV: Beberapa Konsep Dasar dalam Hukum; (5) Bab V: Beberapa Asas dalam Hukum; (6) Bab VI: Berbagai Sistem Hukum di Dunia; (7) Bab VII: Sumber-Sumber Hukum; (8) Bab VIII: Beberapa Aliran dalam Hukum; (9) Bab IX: Metode Penafsiran dalam Hukum; dan (10) Bab X: BidangBidang Studi Hukum.

Atas terbitnya diktat ini, kami menyampaikan terima kasih kepada Dekan Fakultas Syariah IAIN Kediri serta seluruh jajarannya yang telah memberikan kesempatan kepada kami untuk belajar dan mengampu mata kuliah "Pengantar Ilmu Hukum". Di samping itu, ucapakan terima kasih kami juga kepada semua pihak yang telah membantu dan memberikan kontribusi dalam penyusunan diktat ini.

Kami menyadari masih terdapat banyak kekurangan dalam penyusunan diktat ini. Oleh karena itu, kritik dan saran 
yang membangun sangat kami harapkan guna perbaikan dan kesempurnaan karya-karya kami berikutnya.

Kediri, Oktober 2021

Ach. Khiarul Waro Wardani

Hutrin Kamil

Moch. Choirul Rizal 


\section{KATA SAMBUTAN}

Puji syukur kehadirat Allah SWT, atas limpahan rahmat dan hidayah-Nya kita semua masih diberikan nikmat kesehatan, sehingga masih dapat berbagi ilmu pengetahuan. Salawat serta salam semoga selalu tercurahkan kepada Nabi Muhammad SAW.

Kami sebagai pengelola pada Fakultas Syariah Institut Agama Islam Negeri (IAIN) Kediri menyambut gembira atas terbitnya "Diktat Pengantar Ilmu Hukum" yang disusun secara kolaboratif oleh para dosen pengampu mata kuliah "Pengantar Ilmu Hukum" ini. Sebagai catatan perkuliahan yang banyak merujuk pada referensi-referensi terpercaya yang terbit sebelumnya, kami memandang diktat ini dapat disebarluaskan kepada seluruh mahasiswa, baik pada Program Studi Hukum Keluarga Islam, Hukum Ekonomi Syariah, dan Hukum Tata Negara. Tak lain dan bukan, agar mahasiswa mendapatkan tambahan referensi sekaligus pemahaman yang mendasar tentang ilmu hukum.

Atas terbit dan disebarluaskannya diktat ini, kami mengucapkan selamat dan terima kasih kepada para penyusun. Semoga ke depan lahir karya-karya berikutnya dalam rangka menunjang proses pembelajaran di Fakultas Syariah IAIN Kediri. Aamiin.

Kediri, Oktober 2021

Dr. Khamim, M.Ag.

(Dekan Fakultas Syariah IAIN Kediri) 


\section{DAFTAR ISI}

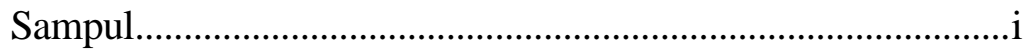

Kata Pengantar .....................................................................ii

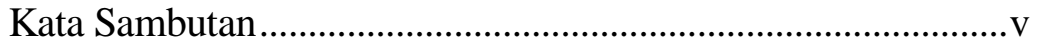

Daftar Isi................................................................................. vii

Bab I : Karakteristik Ilmu Hukum ........................................ 1

Bab II : Pengertian, Fungsi, dan Tujuan Hukum...................11

Bab III : Hukum sebagai Institusi Sosial ................................19

Bab IV : Beberapa Konsep Dasar dalam Hukum ..................25

Bab V : Beberapa Asas dalam Hukum..................................33

Bab VI : Berbagai Sistem Hukum di Dunia .............................37

Bab VII ： Sumber-Sumber Hukum .............................................43

Bab VIII : Beberapa Aliran dalam Hukum ...............................4 47

Bab IX : Metode Penafsiran dalam Hukum ...........................59

Bab X : Bidang-Bidang Studi Hukum..................................67

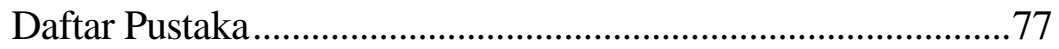

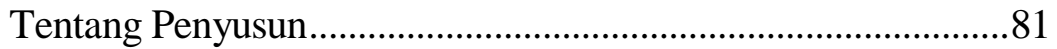





\section{BAB I \\ KARAKTERISTIK ILMU HUKUM}

\subsection{Ilmu Hukum sebagai Ilmu Pengetahuan}

Kata "ilmu" sering dipadankan dengan istilah dalam bahasa Inggris "science" yang mempunyai arti "ilmu pengetahuan". Konsekuensinya, suatu pengetahuan yang tidak diperoleh tanpa melalui prinsip dan prosedur formulasi masalah dan hipotesis serta tidak diverifikasi oleh data hasil observasi dan eksperimen, bukanlah ilmu pengetahuan. ${ }^{1}$ Artinya, ilmu pengetahuan itu harus bersifat empiris.

Di sisi yang lain, kata "ilmu" harus dikembalikan kepada makna yang asli di dalam bahasa latin, yaitu "scientia" yang mempunyai arti "pengetahuan" atau yang dalam bahasa Inggris disebut dengan "knowledge". Dengan menggunakan istilah demikian, pengetahuan yang didapatkan melalui studi-studi nonempiris akan mudah untuk dapat diterima sebagai ilmu, seperti ilmu bahasa, ilmu budaya, ilmu sejarah, begitu juga ilmu hukum. $^{2}$

Suatu bidang studi itu dapat dikatakan sebagai ilmu apabila memenuhi 3 (tiga) kriteria. Pertama, dari sudut ontologi, yaitu bidang studi itu harus mempunyai objek studi yang jelas. Kedua, dari sudut epistimologi, bidang studi itu mempunyai pendekatan dan metodologi mengenai bagaimana ilmu itu disusun, dibina, dan dikembangkan. Ketiga, dari sudut aksiologi, bidang studi itu dapat menunjukkan nilai-nilai teoritis serta kesimpulan-kesimpulan yang logis dan sistematis. ${ }^{3}$ 2018), 1 .

${ }^{1}$ Peter Mahmud Marzuki, Pengantar Ilmu Hukum (Jakarta: Kencana,

2 Ibid., 4-5.

${ }^{3}$ Pipin Syarifin, Pengantar Ilmu Hukum (Bandung: Pustaka Setia, 1999), 14. 
Ilmu hukum mempunyai objeknya sendiri, yaitu hukum. ${ }^{4}$ Ilmu hukum memiliki karakter yang khas. Ciri khas ilmu hukum adalah sifatnya yang normatif. Oleh karena itu, ilmu hukum merupakan ilmu sui generis, yaitu ilmu jenis tersendiri. ${ }^{5}$

Sebagai ilmu sui generis, ilmu hukum tidak dapat diklasifikasikan ke dalam ilmu sosial yang bidang kajiannya kebenaran empiris. Pasalnya, ilmu sosial tidak memberi ruang untuk menciptakan konsep hukum. Studi tersebut hanya berkaitan dengan implementasi konsep hukum dan hanya sering memberi perhatian terhadap kepatuhan individu terhadap aturan hukum. ${ }^{6}$

Ilmu hukum masuk ke dalam bilangan ilmu yang bersifat preskriptif. Artinya, ilmu yang sarat nilai. Ia bersifat menganjurkan, bukan hanya mengemukakan apa adanya. Kebenaran yang hendak diperoleh adalah kebenaran koherensi. Dengan demikian, ilmu hukum bukan termasuk ke dalam bilangan ilmu empiris. ${ }^{7}$

Sementara itu, penelitian yang komprehensif tentang struktur ilmu hukum yang dilakukan oleh Bernard Arief Sidharta, sebagaimana dikutip oleh Josef Mario Monteiro, membuktikan bahwa hukum masih dapat digolongkan sebagai ilmu. Ilmu hukum termasuk di dalam kelompok ilmu praktis atau terapan. ${ }^{8}$

\subsection{Sejarah Timbulnya Ilmu Hukum}

Tradisi peradaban Barat membawa pengaruh yang signifikan terhadap timbulnya ilmu hukum. Tradisi yang dimaksud bersumber kepada peradaban Yunani. ${ }^{9}$

Bermula sejak Dorian yang datang dari utara menduduki pusat kekuasaan Mysia, tidak lama setelah tahun 1.200 SM, hukum dijadikan sebagai prinsip sentral dalam kehidupan. Para 2000), 3 .

${ }^{4}$ Satjipto Rahardjo, Ilmu Hukum (Bandung: PT Citra Aditya Bakti,

${ }^{5}$ Philipus M. Hadjon and Tatiek Sri Djatmiati, Argumentasi Hukum (Yogyakarta: Gadjah Mada University Press, 2017), 1.

${ }^{6}$ Marzuki, Pengantar Ilmu Hukum, 35.

${ }^{7}$ Ibid., 9.

${ }^{8}$ Josef Mario Monteiro, Konsep Dasar Ilmu Hukum (Malang: Setara Press, 2017), 6.

${ }^{9}$ Marzuki, Pengantar Ilmu Hukum, 10. 
pengungsi yang terusir menyeberangi Aegea untuk menetap di ujung Asia Kecil. Di dalam pemukiman yang baru tersebut, mereka menciptakan seperangkat hukum dan sistem pemerintahan yang kuat untuk menjamin kerja sama. Mereka lalu mendirikan negara kota yang dalam bahasa Yunani disebut "polis". ${ }^{0}$

Sejarah berlanjut. Dominasi Athena ternyata kemudian dipatahkan oleh Sparta pada tahun 404 SM. Lalu, Makedonia menaklukkan Sparta tahun 338 SM. Penaklukan tersebut telah melenyapkan kedaulatan polis lokal. Pada tahun 146, Yunani dan Makedonia jatuh ke tangan Romawi hingga kemudian timbulnya hukum Romawi. ${ }^{11}$

Hukum Romawi bersumber dari Corpus Iuris Civilis hasil kodifikasi Kaisar Iustinianus. Hukum Romawi ini yang menjadi acuan hukum Barat. Naskah tersebut terdiri dari 4 (empat) bagian: (1) Caudex, yaitu aturan-aturan dan putusan-putusan yang dibuat oleh para kaisar sebelum Iustinianus; (2) Novellae, yaitu aturan-aturan hukum yang diundangkan oleh Kaisar Iustinianus; (3) Instituti, yaitu suatu buku ajar kecil yang dimaksudkan untuk pengantar bagi mereka yang baru belajar hukum; dan (4) Digesta atau Pandectae, yaitu sekumpulan besar pendapat para yuris Romawi mengenai ribuan proposisi hukum dalam ruang lingkup hukum perdata, hukum pidana, hukum tata negara, dan cabangcabang hukum yang mengatur warga negara Romawi. ${ }^{12}$

Karya Iustinianus yang diketemukan di Italia itu menjadi objek studi hukum secara sistematis dengan menggunakan metode skolastik, yaitu metode analisis dan sistesis yang diterapkan terhadap naskah-naskah hukum. Metode tersebut diajarkan di universitas, khususnya di Fakultas Hukum Universitas Bologna yang didirikan terutama untuk mempelajari teks-teks Iustinianus tersebut. ${ }^{13}$

Di samping itu, sejarah timbulnya ilmu hukum tidak terlepas dari peranan glossator dan commentator. Para glossator

\footnotetext{
${ }^{10}$ Ibid., 10-11.

11 Ibid., 12.

12 Ibid., 13-16.

13 Ibid., 14-16.
} 
adalah para dosen di Fakultas Hukum Universitas Bologna. Mereka melakukan glossir, yaitu memberikan keterangan kata demi kata dan baris demi baris terhadap bahasa teks Digesta setelah melalui proses pembacaan dan koreksi, mengingat teks yang dimaksud sangat sukar dipahami. ${ }^{14}$

Pekerjaan glossator diganti oleh commentator. Pada abad XIII, commentator bekerja atas dasar-dasar yang telah diletakkan oleh glossator. Mereka mempersiapkan komentar-komentar yang sistematis terhadap masalah-masalah hukum. Pekerjaan commentator memberikan sumbangan dalam mengantarkan mempraktikkan hukum yang tertuang di dalam Corpus Iuris Civilis. Mengingat pekerjaan yang demikian, commentator sering memberikan nasihat kepada pihak-pihak yang beperkara dan juga ke pengadilan untuk perkara-perkara yang spesifik. ${ }^{15}$

\subsection{Ruang Lingkup Ilmu Hukum}

Menurut Jan Gijssels dan Mark van Hoecke, sebagaimana dikutip oleh Peter Mahmud Marzuki, terdapat 3 (tiga) tingkatan ilmu hukum, yaitu dogmatika hukum, teori hukum, dan filsafat hukum. Demikian pula menurut Richard A. Posner. ${ }^{16}$ Tingkatan keilmuan dalam ilmu hukum tersebut yang kemudian dapat disebut sebagai ruang lingkup ilmu hukum.

Dogmatika hukum memiliki bidang kajian pada hukum yang sedang berlaku dalam suatu sistem hukum tertentu. Bukan hanya hukum positif (yang berlaku karena dibuat oleh penguasa), tetapi juga hukum kebiasaan dan praktik-praktik yang sudah diterima sebagai hukum oleh masyarakat. ${ }^{17}$

Teori hukum mempelajari hukum dengan tujuan untuk mendapatkan pemahaman yang lebih dalam dan lebih baik mengenai hukum. Oleh karena itu, tugas teori hukum, pertama, memberikan landasan teoritis, baik dalam pembentukan hukum maupun penegakan hukum. Kedua, mengemukakan metode yang tepat dalam penegakan hukum. Adapun pengembangan teori

\footnotetext{
${ }^{14}$ Ibid., 17.

15 Ibid., 17-18.

${ }^{16}$ Ibid., 20-21.

17 Ibid., 21.
} 
bukan hanya teori belaka, melainkan teori yang dapat diterapkan. ${ }^{18}$

Sementara itu, filsafat hukum mempelajari gagasan dasar dan prinsip-prinsip hukum yang merupakan pancaran dari moral. ${ }^{19}$ Proses mempelajari tersebut bersoal pada "hakikat hukum" dan "dasar-dasar bagi kekuatan mengikat dari hukum". ${ }^{20}$

\subsection{Antara Ilmu Hukum Normatif dengan Empiris}

Perdebatan antara istilah "ilmu hukum normatif" dengan "ilmu hukum empiris" belum menemukan titik temu. Perdebatan tersebut berimplikasi pula pada perselisihan terkait konsekuensi metodologinya. Dapat dikatakan sebagai perdebatan yang abadi ${ }^{21}$ di dalam studi hukum di Indonesia.

Pada prinsipnya, ilmu (hukum) normatif bekerja untuk menemukan tolok pembanding yang akan dapat dipakai untuk menentukan apakah suatu perbuatan dapat dinilai sebagai suatu perbuatan yang dapat dibenarkan atau dipersalahkan. Ilmu ini berkenaan dengan kebenaran ipso jure, yaitu kebenaran menurut keharusan suatu aturan atau ajaran. ${ }^{22}$

Ilmu (hukum) normatif termasuk dalam bilangan ilmu $a$ priori. Hal tersebut disebabkan tolok ajaran yang mengharuskan (das sollen) hadir mendahului fakta (das sein) yang hendak ditolok benar atau salahnya. Penolokan tersebut dilakukan berdasarkan suatu prosedur penalaran yang disebut deduksi. ${ }^{23}$ Kebenaran yang hendak diperoleh adalah kebenaran koherensi.

18 Ibid., 26.

19 Ibid.

${ }^{20}$ Rahardjo, Ilmu Hukum, 339.

21 Widodo Dwi Putro menyebutnya sebagai perselisihan permanen. Padahal, pertikaian antara "Metodologi Penelitian Hukum Normatif" dengan "Metodologi Penelitian Hukum Empiris" di Indonesia lebih kepada persoalan suka atau tidak suka (almamater mana, siapa guru besarnya, dan sebagainya), bukan pada pertikaian paradigma dan persoalan epistimologi. Lihat, Widodo Dwi Putro, Kritik Terhadap Paradigma Positivisme Hukum (Yogyakarta: Genta Publishing, 2011), 67.

${ }^{22}$ Soetandyo Wignjosoebroto, Hukum: Konsep Dan Metode (Malang: Setara Press, 2013), 11.

${ }^{23}$ Ibid., 11-12. 
Menurut teori koherensi, kebenaran tidak ditentukan melalui kesesuaian antara proposisi dengan kenyataan, melainkan dalam relasi antara proposisi baru dengan proposisi yang sudah diterima sebagai kebenaran. Pada praktiknya, fakta diandaikan sebagai premis minor, sedangkan teori dan proposisi yang dianggap benar diandaikan sebagai premis minor. Oleh karena teori kebenaran yang demikian, hukum harus dapat diprediksikan, stabil, dan menjamin kepastian. ${ }^{24}$

Di sisi yang lain, ilmu (hukum) empiris bekerja untuk menemukan bukti-bukti dari alam fakta yang tersimak secara indrawi, yaitu apakah suatu perbuatan betul-betul telah terjadi atau sebetulnya tidak atau mungkin belum terjadi. Ilmu ini berkenaan dengan kebenaran ipso facto, yaitu kebenaran yang dibenarkan berdasarkan bukti-bukti nyata faktual yang diperoleh dari alam indrawi. ${ }^{25}$

Ilmu (hukum) empiris termasuk dalam bilangan ilmu $a$ posteriori. Hal tersebut disebabkan teori datang belakangan dan terwujud sebagai simpulan yang ditarik secara logis dari data. Penyimpulan seperti itu dilakukan berdasarkan suatu prosedur logika induksi. ${ }^{26}$ Ilmu (hukum) empiris dapat dikaji melalui penelitian kualitatif atau kuantitatif yang sangat bergantung pada sifat datanya. ${ }^{27}$ Kebenaran yang hendak diperoleh adalah kebenaran korespondensi.

Kebenaran korespondensi mementingkan peranan pengalaman dan pengamatan empiris terhadap objek pengetahuan. Oleh karena itulah ia bersifat a posteriori (didahului pengalaman). Menurut teori kebenaran korespondensi, sesuatu dinyatakan benar apabila sesuai dengan kenyataan dan dapat diverifikasi secara empiris. Di dalam studi hukum, teori kebenaran korespondensi bermanfaat untuk melihat kenyataan hukum, misalnya, melihat efektivitas bekerjanya hukum di masyarakat. ${ }^{28}$

${ }^{24}$ Putro, Kritik Terhadap Paradigma Positivisme Hukum, 237.

25 Wignjosoebroto, Hukum: Konsep Dan Metode, 11.

26 Ibid., 12.

${ }^{27}$ Hadjon and Djatmiati, Argumentasi Hukum, 3.

${ }^{28}$ Putro, Kritik Terhadap Paradigma Positivisme Hukum, 238. 
Peter Mahmud Marzuki berpandangan, istilah ilmu hukum empiris merupakan sesuatu yang bersifat contradictio in terminis. Hal tersebut mengingat apabila dilihat secara etimologis, ilmu hukum yang merupakan terjemahan dari bahasa Inggris "jurisprudence" berasal dari bahasa Latin "ius" dan "prudentia" yang bukan merupakan suatu pengetahuan tentang sesuatu yang bersifat empiris. ${ }^{29}$

Pada pendapat yang lain, sesungguhnya objek kajian ilmu hukum itu bersifat dualistis. Artinya, antara ilmu hukum normatif dengan ilmu hukum empiris itu menyatu, yaitu sebagai kaidah (normatif) dan juga gejala sosial (empiris), sehingga tidak perlu diperdebatkan. Pipin Syarifin menjelaskan, ilmu hukum normatif bersifat normatif karena ia berhubungan dengan masalah apa yang seharusnya terjadi dalam masyarakat, sedangkan ilmu hukum empiris bersifat empiris karena ia berhubungan dengan apa yang sebenarnya terjadi. ${ }^{30}$ Bahkan, Lukman Santoso AZ dan Yahyanto menyebutkan sifat dari hukum yang normatif dan juga empiris termasuk sebagai ruang lingkup di dalam ilmu hukum. ${ }^{31}$

Perdebatan tersebut sebenarnya tidak perlu diteruskan, mengingat ilmu hukum yang normatif nyatanya tidak dapat dilepaskan dari fakta sosial. Widodo Dwi Putro menegaskan, pertama, hukum yang paling formal sekalipun ia tetap harus berpijak pada basis sosialnya (masyarakat). Oleh karena itu, hukum membutuhkan evaluasi terus-menerus dari kenyataan sosial. Kedua, bukti keterikatan hukum pada kenyataan sosial adalah peradilan. Pada praktiknya, hakim harus memeriksa faktafakta sebelum menjatuhkan putusannya. Ketiga, proses-proses hukum bukan hanya suatu perjalanan penerapan atau penafsiran peraturan-peraturan hukum saja, tetapi proses terwujudnya tujuan-tujuan sosial di dalam hukum. Keempat, terlebih lagi, hukum positif itu tidak pernah lengkap (dan tidak mungkin

${ }^{29}$ Marzuki, Pengantar Ilmu Hukum, 28-29.

${ }^{30}$ Syarifin, Pengantar Ilmu Hukum, 12.

${ }^{31}$ Lihat, Lukman Santoso AZ and Yahyanto, Pengantar Ilmu Hukum (Sejarah, Pengertian, Konsep Hukum, Aliran Hukum, Dan Penafsiran Hukum) (Malang: Setara Press, 2016), 4. 
lengkap) mengatasi, melingkupi, dan mengantisipasi persoalan di tengah-tengah masyarakat. ${ }^{32}$

Atas adanya perdebatan yang abadi tersebut, kiranya dapat mengambil sikap yang bijak sebagaimana dituturkan oleh Philipus M. Hadjon dan Tatiek Sri Djatmiati: ${ }^{33}$

“... janganlah mengempiriskan segi-segi normatif ilmu hukum dan sebaliknya janganlah menormatifkan segi-segi empiris dalam penelitian hukum. Dalam kajian normatif sebaiknya berpegang pada tradisi keilmuan hukum itu sendiri, sedangkan dalam kajian ilmu hukum empiris sebaiknya digunakan metode-metode penelitian empiris yang sesuai."

\subsection{Tentang Istilah "Pengantar Ilmu Hukum"}

Istilah "Pengantar Ilmu Hukum" atau yang lazim disingkat dan disebut "PIH" merupakan terjemahan langsung dari istilah dalam bahasa Belanda "Inleiding tot de rechtswetenschaft" yang mempunyai arti suatu mata kuliah pendahuluan atau pembuka ke arah ilmu pengetahuan hukum ${ }^{34}$ yang diberikan di Rechtshoge School (RHS) atau Sekolah Tinggi Hukum di Batavia pada zaman Hindia Belanda yang didirikan pada tahun 1924. Sementara itu, istilah PIH pertama kali dipergunakan ketika Perguruan Tinggi Gajah Mada didirikan di Yogyakarta pada 13 Maret $1946 .^{35}$

PIH adalah suatu mata kuliah dasar yang mengantarkan atau menunjukkan jalan ke arah cabang-cabang ilmu hukum. ${ }^{36}$ $\mathrm{PIH}$ memberikan pandangan umum secara ringkas mengenai seluruh ilmu pengetahuan hukum. Di samping itu, PIH menjelaskan kedudukan ilmu hukum di samping ilmu-ilmu yang

32 Putro, Kritik Terhadap Paradigma Positivisme Hukum, 119-122.

${ }^{33}$ Hadjon and Djatmiati, Argumentasi Hukum, 5.

${ }^{34}$ Syarifin, Pengantar Ilmu Hukum, 11.

35 Dudu Duswara Machmudin, Pengantar Ilmu Hukum (Sebuah Sketsa) (Bandung: PT Refika Aditama, 2001), 1. Lihat juga, AZ and Yahyanto, Pengantar Ilmu Hukum (Sejarah, Pengertian, Konsep Hukum, Aliran Hukum, Dan Penafsiran Hukum), 1.

${ }^{36}$ Syarifin, Pengantar Ilmu Hukum, 11. 
lain. ${ }^{37}$ Sebagai mata kuliah dasar keahlian, PIH memberikan landasan guna mendukung mata kuliah lain, sehingga dapat membantu memudahkan dan melancarkan studi mata kuliah hukum yang bukan bersifat pengantar lagi. ${ }^{38}$

${ }^{37} \mathrm{AZ}$ and Yahyanto, Pengantar Ilmu Hukum (Sejarah, Pengertian, Konsep Hukum, Aliran Hukum, Dan Penafsiran Hukum), 1.

${ }^{38}$ Machmudin, Pengantar Ilmu Hukum (Sebuah Sketsa), 3. 


\section{BAB II \\ PENGERTIAN, FUNGSI, DAN TUJUAN HUKUM}

\subsection{Beberapa Pengertian tentang Hukum}

Dalam sebuah studi hukum, hal yang menjadi pertanyaan adalah apakah sebenarnya hukum itu? Hal ini tentu menjadi pertanyaan di dalam hati bagi siapa saja yang ingin mempelajari hukum atau sedang mempelajari hukum.

Dalam konteks ini, sering kali seseorang membuat sesuatu pengertian dengan menggunakan susunan kata yang indah dan mudah dipahami. Hal tersebut berlaku juga dalam memberikan pengertian terhadap hukum.

Kita semua mengetahui bahwa suatu pengertian memang indah, lebih-lebih yang muncul dari benaknya sendiri. Dalam arti lain, tidak meng-copy atau meniru pengertian yang disampaikan orang lain. Pengertian yang dimaksud bersumber, misalnya, dari ilmu pengetahuannya sendiri (belajar) dari sebuah penelitian.

Mampu memberikan pengertian terhadap sesuatu tentu memiliki manfaat tersendiri bagi siapa saja yang ingin mengetahui, bahkan mendalami sesuatu. Pasalnya, dengan mampu memberikan pengertian terhadap sesuatu, maka seseorang dapat memahami ke mana arah sesuatu tersebut dalam pengkajian yang sangat luas. Hal tersebut juga berlaku dalam studi hukum.

Di dalam studi hukum, perlu dipahami bahwa tidak ada pengertian baku di dalam memaknai hukum. Hal demikian sangat mungkin terjadi, mengingat setiap orang memiliki batas pemikiran tersendiri dalam memaknai hukum. Misalnya, di dalam hukum itu memuat asas keadilan dan setiap orang memiliki pandangan tersendiri dalam sebuah keadilan, sehingga akan 
berdampak terhadap munculnya berbagai istilah di dalam hukum. Sebagaimana yang disampaikan oleh Sudiman Kartohadiprodjo:

“... jikalau kita menanyakan apakah yang dinamakan hukum, maka kita akan menjumpai tidak adanya persesuaian pendapat. Berbagai perumusanlah yang dikemukakan." 39

Dengan demikian, hukum tidak memiliki pengertian yang paten. Pernyataan tersebut telah disepakati oleh banyak pakar hukum dan hampir semua sarjana hukum mengatakan hal yang sama. Demikian pula yang disampaikan oleh Van Apeldoorn, "hampir semua sarjana hukum memberikan pembatasan hukum yang berlainan". ${ }^{40}$ Artinya, ia juga memiliki pendapat sama dengan Sudiman Kartohadiprodjo. Pendapat kedua tokoh tersebut juga disepakati oleh seluruh pakar, praktisi, atau sarjana hukum.

Lalu, bagaimana pengertian hukum menurut para pakar hukum dalam mendefinisikan hukum?

Berikut adalah beberapa pengertian hukum menurut para pakar hukum: ${ }^{41}$

- Menurut Aristoteles, hukum hanya sebagai kumpulan peraturan yang tidak hanya mengikat masyarakat tetapi juga hakim. Dengan demikian, hukum mengikat seluruh manusia tanpa kecuali.

- Menurut Plato, hukum merupakan peraturan-peraturan yang teratur dan tersusun baik yang mengikat masyarakat. Dengan demikian, hukum adalah aturan yang sistematis dan mengikat masyarakat.

- Menurut Hugo Grotius, hukum adalah aturan tentang tindakan moral yang mewajibkan apa yang benar. Dengan

39 Sudiman Kartohadiprodjo, Pengantar Tata Hukum Di Indonesia, $1956,1$.

${ }^{40}$ C.S.T. Kansil, Pengantar Ilmu Hukum Dan Tata Hukum Indonesia (Bogor: Balai Pustaka, 1986), 35.

${ }^{41}$ Lihat, Rudi Pradisetia Sudirdja, "Mencari Definisi Hukum Menurut Para Ahli Dan Membuat Kesimpulan," last modified 2010, accessed September 6, 2021, http://www.rudipradisetia.com/2010/09/mencari-definisihukum-menurut-para_14.html. 
demikian, hukum adalah aturan yang mewajibkan kita berbuat benar.

- Menurut Tullius Cicero, hukum adalah akal tertinggi yang ditanamkan oleh alam dalam diri manusia untuk menetapkan apa yang boleh dan apa yang tidak boleh dilakukan. Dengan demikian, hukum adalah pemikiran positif yang bersumber dari alam untuk manusia guna mengatur apa yang boleh dan yang tidak boleh dilakukan.

- Menurut Thomas Hobbes, hukum adalah perintah-perintah dari orang yang memiliki kekuasaan untuk memerintah dan memaksakan perintahnya kepada orang lain. Dengan demikian, hukum timbul dari penguasa yang memaksakan perintahnya kepada orang lain.

- Menurut Rudolf von Jhering, hukum adalah keseluruhan peraturan yang memaksa yang berlaku dalam suatu negara. Dengan demikian, hukum adalah aturan yang memaksa di suatu negara.

- Menurut Utrecht, hukum merupakan himpunan petunjuk hidup berupa perintah dan larangan yang mengatur tata tertib dalam suatu masyarakat yang seharusnya ditaati oleh seluruh anggota masyarakat. Oleh karena itu, pelanggaran petunjuk hidup tersebut dapat menimbulkan tindakan oleh pemerintah. Dengan demikian, hukum adalah perintah dan larangan guna mengatur tata tertib di masyarakat yang harus ditaati dan menimbulkan sanksi.

- Menurut Abdulkadir Muhammad, hukum adalah segala peraturan tertulis dan tidak tertulis yang mempunyai sanksi yang tegas terhadap pelanggarnya. Dengan demikian, hukum adalah aturan yang bersanksi tegas.

- Menurut J.C.T. Simorangkir dan Woerjono Sastropranoto, hukum itu ialah peraturan-peraturan yang bersifat memaksa, yang menentukan tingkah laku manusia dalam lingkungan masyarakat, yang dibuat oleh badan-badan resmi yang berwajib, pelanggaran-pelanggaran yang dikenai tindakantindakan hukum tertentu. Dengan demikian, hukum adalah 
aturan yang memaksa yang dibuat oleh badan resmi yang didalamnya terdapat sanksi untuk pelanggarnya.

- Menurut R. Soeroso, hukum, secara umum, adalah himpunan peraturan yang dibuat oleh yang berwenang dengan tujuan untuk mengatur tata kehidupan bermasyarakat yang mempunyai ciri memerintah dan melarang serta mempunyai sifat memaksa dengan menjatuhkan sanksi hukuman bagi yang melanggarnya. Dengan demikian, hukum adalah aturan yang dibuat oleh badan yang berwenang yang bertujuan mengatur kehidupan masyarakat dengan ciri memerintah, melarang, dan sifatnya memaksa dan juga memiliki sanksi untuk pelanggarnya.

- Menurut C.S.T. Kansil, hukum itu mengadakan ketatatertiban dalam pergaulan manusia, sebagai keamanan dan ketertiban terpelihara. Dengan demikian, hukum merupakan alat pengatur guna memelihara kehidupan menjadi aman dan tertib.

- Menurut S.M. Amin, hukum adalah kumpulan peraturanperaturan yang terdiri dari norma dan sanksi-sanksi. Dengan demikian, hukum adalah aturan yang terdiri dari norma dan sanksi.

- Menurut M.H. Tirtaatmidjaja, hukum adalah semua aturan (norma) yang harus diturut dalam tingkah laku tindakantindakan dalam pergaulan hidup dengan ancaman mesti mengganti kerugian. Jika melanggar aturan-aturan itu, yang membahayakan diri sendiri atau harta, maka si pelanggar akan kehilangan kemerdekaannya sebab dijatuhkan pidana terhadapnya. Dengan demikian, hukum adalah aturan yang harus dipatuhi dan terdapat sanksi bagi pelanggarnya.

- Menurut Mochtar Kusumaatmaja, hukum adalah keseluruhan kaidah-kaidah serta asas-asas yang mengatur pergaulan hidup manusia dalam masyarakat yang bertujuan memelihara ketertiban, yang meliputi lembaga-lembaga dan proses-proses guna mewujudkan berlakunya kaidah-kaidah itu sebagai kenyataan dalam masyarakat. Dengan demikiann, hukum adalah aturan masyarakat bertujuan menertibkan yang 
dilakukan oleh lembaga dan melalui proses guna mewujudkannya.

- Menurut Wirjono Prodjodikoro, hukum adalah rangkaian peraturan-peraturan mengenai tingkah laku orang-orang sebagai anggota suatu masyarakat. Dengan demikian, hukum adalah aturan yang mengatur tingkah laku manusia.

- Menurut Van Vollenhoven, hukum adalah suatu gejala dalam pergaulan hidup yang bergejolak terus-menerus dalam keadaan bentur-membentur tanpa henti-hentinya dengan gejala lainnya. Dengan demikian, hukum timbul dari pergaulan hidup yang terus berbenturan dengan gejala lainya selama pergaulan hidup itu masih ada.

- Menurut Soerojo Wignjodipoero, hukum adalah himpunan peraturan-peraturan hidup yang bersifat memaksa, berisikan suatu perintah, larangan atau perizinan untuk berbuat tidak berbuat sesuatu serta dengan maksud untuk mengatur tata tertib dalam kehidupan masyarakat. Dengan demikian, hukum adalah aturan hidup yang memaksa dan di dalamnya terdapat perintah, larangan, atau perizinan dengan tujuan mengatur tata tertib masyarakat.

Dari beberapa pengertian hukum yang dikemukakan oleh para pakar hukum di atas, dapat disimpulkan bahwa hukum adalah segala bentuk peraturan yang timbul dari masyarakat sebagai subjek hukum (manusia dan badan hukum) yang di dalamnya memuat aturan-aturan berkaitan dengan larangan dan perintah yang bersifat memaksa dan mengikat dengan diberlakukan sanksi bagi siapa saja yang melanggar atas larangan dan perintah yang telah dibuat dan/atau disepakati, baik secara tertulis ataupun tidak.

\subsection{Fungsi Hukum}

Sudah menjadi takdirnya, sebagai subjek hukum, manusia maupun badan hukum membutuhkan suatu pegangan atau pedoman dalam melaksanakan segala aktivitasnya. Dalam studi hukum, hukum diasosiasikan sebagai pegangan atau pedoman bagi subjek hukum yang notabene merupakan pembawa hak dan kewajiban. 
Berkaitan dengan subjek hukum dan hukum sebagai pegangan atau pedoman bagi subjek hukum, maka perlu dipahami bahwa hukum memiliki fungsi. Sebagaimana yang telah dijelaskan Achmad Ali, hukum memiliki banyak sekali fungsi dalam kehidupan manusia. Menurutnya, fungsi hukum sebagai a tool of social control, a tool of social engineering, simbol, political instrument, dan integrator. ${ }^{42}$

Di tengah-tengah masyarakat, misalnya, hukum yang selalu menjadi perhatian adalah berkaitan dengan hukum perdata dan hukum pidana. Lalu, apa fungsi hukum pidana dan perdata?

Fungsi hukum pidana ada 2 (dua). Pertama, fungsi preventif, yaitu untuk menakut-nakuti setiap orang agar mereka tidak melakukan perbuatan pidana. Kedua, fungsi represif, yaitu untuk mendidik orang yang telah melakukan perbuatan yang tergolong perbuatan pidana, agar mereka menjadi orang yang baik dan dapat diterima kembali dalam masyarakat. ${ }^{43}$

Fungsi hukum perdata juga ada 2 (dua). Pertama, fungsi materiil, yaitu untuk mengatur subjek hukum terkait hak dan kewajibannya. Artinya, hukum perdata mengatur semua kepentingan perdata dari subjek hukum. Kedua, fungsi formal, yaitu untuk mempertahankan hukum perdata dari subjek hukum melalui mekanisme peradilan. ${ }^{44}$

\subsection{Tujuan Hukum}

Dalam diwujudkannya hukum sebagai sebuah peraturan tidaklah tanpa alasan. Alasan untuk tercapainya sebuah keadilan, kepastian, ketertiban, kedamaian, dan kebikjasanaan adalah bagian dari tujuan utama hukum itu sendiri.

Hal tersebut sesuai dengan yang disampaikan oleh Mochtar Kusumaatmajda dalam bukunya yang berjudul "Fungsi dan Perkembangan Hukum dalam Pembangunan Nasional". Ia mengatakan, secara teori, tujuan hukum adalah tercapainya

42 Achmad Ali, Menguak Tabir Hukum (Bogor: Ghalia Indonesia, 2011), 70 .

43 J.B. Daliyo, Pengantar Hukum Indonesia (Jakarta: PT Prenhallindo, 2001), 91.

44 Ibid. 
keadilan. Untuk mencapai ketertiban pergaulan antar manusia dalam masyarakat harus mencerminkan kepastian hukum. Hukum harus dilaksanakan dan ditegakkan jika terjadi suatu perkara itulah kepastian hukum. ${ }^{45}$

Dengan demikian, mengingat manusia merupakan subjek hukum, tentulah manusia sangat diuntungkan dari terwujudnya hukum dalam kehidupannya. Keuntungan tersebut, baik secara personal ataupun kelompok (sosial).

Pada tahapan berikutnya, dengan tercapainya tujuan hukum, maka akan tercipta tatanan kehidupan subjek hukum yang maju dengan semua tatanan ketertiban yang ada. Sementara itu, adapun hak dan kewajiban yang diperjuangkan oleh subjek hukum akan terpenuhi. Begitu juga, asas-asas hukum yang berkaitan dengan keadilan akan terwujud.

45 Mochtar Kusumaatmadja, Fungsi Dan Perkembangan Hukum Dalam Pembangunan Nasional (Bandung: Bina Cipta, 1970), 2. 


\section{BAB III \\ HUKUM SEBAGAI INSTITUSI SOSIAL}

\subsection{Hukum dan Masyarakat}

Keterkaitan hukum dan masyarakat merupakan sebuah keterikatan yang tidak dapat dipisahkan. Keduanya memiliki hubungan timbal balik. Artinya, keberadaan hukum merupakan keberadaan masyarakat. Jika terjadi suatu konflik dalam masyarakat, maka hukum dapat menjadi wadah terhadap konflik yang terjadi dalam masyarakat. Sebaliknya, ada atau tidaknya konflik yang terjadi dalam masyarakat, hukum telah mengatur agar konflik tersebut tidak terjadi.

Dalam makna yang lebih luas, keberadaan hukum dalam masyarakat tidak hanya mengatur masyarakat untuk terciptanya ketertiban dan sebagai alat penyelesai konflik saja. Lebih dari itu, keberadaan hukum dalam masyarakat juga menjadi alat edukasi untuk memahami makna hukum dan makna masyarakat (manusia) dalam kehidupan sosial.

Mengingat manusia dalam kehidupan masyarakat sebagai makhluk sosial yang semakin hari semakin berkembang dan komplek, maka perlu kiranya hukum menyesuaikan perubahanperubahan seiring dengan perkembangan masyarakat. Idealnya, pembentukan hukum (baca: peraturan perundang-undangan) seharusnya mampu mengeleminasi setiap konflik yang diperkirakan akan terjadi dalam masyarakat. ${ }^{46}$

Pada pembentukan hukum yang kemudian berlaku, tentu ada capaian yang nantinya akan berdampak terhadap perubahan masyarakat. Dalam capaian tersebut, hukum bertugas membagi wewenang dan mengatur cara memecahkan masalah hukum serta

${ }^{46}$ Marwan, Pengantar Ilmu Hukum (Jakarta: Ghalia Indonesia, 2004), 72. 
memelihara kepastian hukum di dalam masyarakat. ${ }^{47}$ Kepastian hukum inilah yang nantinya berkaitan erat dengan gerak masyarakat sebagai subjek hukum, misalnya, dalam menerima hak dan dapat melaksanakan kewajibannya.

Kepastian hukum dalam masyarakat juga merupakan sesuatu yang sangat penting untuk dipahami. Hal ini mengingat ada keterkaitan peran antara hukum dengan masyarakat. Pertama, hukum menjadi community social control. Artinya, dengan dengan adanya hukum, maka hukum dapat mengatur semua tingkah laku subjek hukum untuk berjalan sesuai aturan yang telah disepakati dan masyarakat akan mendapatkan kebebeasannya sesuai dengan aturan yang disepakati pula.

Kedua, hukum menjadi means of social interaction. Artinya, hukum dapat berfungsi sebagai alat atau sarana untuk memfasilitasi kebutuhan masyarakat dalam melakukan interaksi sosial, sehingga ada korelasi hukum dalam proses interaksi yang dilakukan subjek hukum.

Ketiga, hukum menjadi certain circumstances in social. Artinya, hukum dapat menjadi sarana atau alat untuk menciptakan suasana atau keadaan tertentu. Dengan demikian, seluruh keadaan yang timbul dari masyarakat harus sesuai dengan kaidah-kaidah hukum yang berlaku. Berikut juga harus sesuai dengan norma dan nilai yang berlaku di dalam masyarakat tersebut. Kendati suasana atau keadaan tersebut adalah sesuatu yang baru, namun tetap harus sesuai dengan kaidah hukum, norma, dan nilai yang berlaku dalam masyarakat.

Dengan demikian, jika telah dipahami bahwa ada korelasi antara hukum dan masyarakat, maka perlu kiranya ada upaya upgrade kebijakan hukum yang dilakukan penguasa (pemerintahan) yang sesuai dengan kebutuhan masyarakat. Mengingat pola kehidupan masyarakat yang semakin hari semakin berkembang, maka kebijakan hukumpun juga harus menyesuaikan.

47 Sudikno Mertokusumo, Mengenal Hukum (Suatu Pengantar) (Yogyakarta: Liberty, 2008), 71. 


\subsection{Hukum dan Kebiasaan}

Kebiasaan atau custom di dalam pembahasan hukum merupakan bagian dari sumber-sumber hukum. Artinya, tentu ada korelasi antara hukum dengan kebiasaan. Lalu, apa yang di maksud dengan kebiasaan?

Di dalam Kamus Besar Bahasa Indonesia (KBBI), kebiasaan adalah sesuatu yang biasa dilakukan. Kebiasaan juga berarti pola untuk melakukan tanggapan terhadap situasi tertentu yang dipelajari oleh seorang individu dan yang dilakukannya secara berulang untuk hal yang sama. ${ }^{48}$ Sementara itu, Lexy J. Moleong menyebutkan, kebiasaan merupakan cara berbuat atau bertindak yang dimiliki seseorang dan diperolehnya melalui proses belajar cara tersebut bersifat tetap, seragam, dan otomatis. $^{49}$

Kebiasaan dalam perspektif hukum dapat diartikan sebagai bentuk pola kehidupan masyarakat yang terjadi berulangulang dalam waktu yang lama. Pola yang berulang-ulang tersebut menjadi pedoman hidup dalam berpikir, bersikap atau bertindak, dan berkeyakinan.

Dari kebiasaan yang timbul dari masyarakat inilah yang nantinya akan menjadi suatu pertimbangan menilai suatu perbuatan yang dilakukan oleh subjek hukum. Bahkan, dapat menjadi sumber hukum, yang kemudian diberlakukan di tengahtengah masyarakat dalam bentuk hukum yang konstitusional. Dalam hal ini, harus dapat diterima bahwa hukum yang timbul dari kebiasaan tersebut dapat bersifat tertulis (peraturan perundang-undangan) ataupun tidak tertulis (adat).

\subsection{Hukum dan Kekuasaan}

Mengkaji hukum dan kekuasan menjadi menarik jika ditarik di dalam berbagai hal. Baik dalam bidang hukum, ekonomi, sosial, agama, bahkan politik. Kenapa kajian ini menjadi menarik?

${ }^{48}$ Departemen Pendidikan Nasional, Kamus Besar Bahasa Indonesia (Jakarta: Balai Pustaka, 2001), 192.

49 Lexy J. Moleong, Metodologi Penelitian Kualitatif (Bandung: Alumni, 2007), 20. 
Keduanya, baik hukum maupun kekuasaan, adalah sesuatu yang tidak dapat dipisahkan satu dengan yang lainnya. Seperti halnya 2 (dua) sisi keping mata uang. Kekuasaan merupakan kewenangan yang diperoleh seseorang atau sebuah kelompok untuk menjalankan kewenangan tersebut. Adapun yang memperoleh kewenangan tidak dapat melakukan segala hal di luar kewenangannya. Di dalam kewenangan tersebut memunculkan dampak terhadap yang memiliki kewenangan untuk melakukan pengawasan atau kontrol terhadap wewenang yang diperoleh.

Sebagai gambaran atau contoh sebuah pengawasan yang dilakukan oleh penguasa, dalam hal ini adalah pemerintah, memiliki pengawasan terhadap rakyat yang mendiami suatu negara tertentu. Pengawasan (controling), yaitu suatu kegiatan yang ditujukan untuk menjamin agar penyelenggaraan negara sesuai dengan rencana. Jika dikaitkan dengan hukum pemerintahan, maka pengawasan dapat diartikan sebagai suatu kegiatan yang ditujukan untuk menjamin sikap pemerintah agar berjalan sesuai dengan hukum yang berlaku. Pengawasan juga berarti suatu kegiatan yang ditujukan untuk menjamin terlaksananya penyelengaraan negara oleh lembaga-lembaga kenegaraan sesuai dengan hukum yang berlaku. ${ }^{50}$

Dalam konteks kekuasaan, tentu tidak hanya berbicara tentang pemerintahan negara di tingkat pusat saja. Pembicaraan mengenai kekuasaan juga dalam konteks yang lebih kecil, seperti kekuasaan terhadap daerah kabupaten/kota, kecamatan, desa, dusun, rukun warga, rukun tetangga, bahkan dalam keluarga.

Dari pengertian di atas, dapat dipahami bahwa kekuasaan dan hukum memiliki korelasi yang sangat kuat. Namun, antara hukum dengan kekuasaan bersifat terbatas. Ada batas kekuasaan, sehingga tidak dapat semena-mena dalam membuat sebuah aturan atau hukum. Hal tersebut tergantung seberapa luas kekuasaannya, maka sebatas itulah kuasanya membuat sebuah peraturan atau hukum.

50 Sri Soemantri, Ketatanegaraan Indonesia Dalam Sistem Politik Indonesia (Jakarta: Pustaka Sinar Harapan, 1993), 281. 
Ambil contohnya, misalnya, Indonesia sebagai negara demokrasi yang konstitusional tetaplah memiliki batasan dalam kekuasan dan wewenangnya. Seperti yang disampaikan oleh Miriam Budiarjo, ciri khas dari negara demokrasi konstitusional ialah gagasan pemerintahan yang demokratis, yaitu pemerintahan yang terbatas kekuasaannya dan tidak dibenarkan bertindak sewenang-wenang terhadap warga negaranya. ${ }^{51}$ Pembatasanpembatasan atas kekuasaan pemerintah yang dimaksud tercantum dalam konstitusi, sehingga disebut pemerintahan berdasarkan konstitusi (constitutional government). ${ }^{52}$

Di samping itu, selain wewenang hukum dan batasan hukum yang dimiliki suatu kekuasaan, kekuasaan juga memiliki fungsi sebagai legal tools untuk membentuk sebuah aturan atau hukum, penegakan hukum, dan dapat juga sebagai pelaksanakan hukum. Di sisi yang lain, fungsi hukum terhadap kekuasaan meliputi alat untuk melegalisasi atau menjustifikasi kekuasaan, alat untuk mengatur dan mengontrol kekuasaan, serta juga alat untuk mengawasi pertanggungjawaban kekuasaan. ${ }^{53}$

\subsection{Hukum dan Norma-Norma Sosial Lainnya}

Manusia adalah makhluk sosial. Manusia tidak dapat hidup sendiri. Keberadaan manusia tergantung dengan manusia yang lainnya. Dalam memenuhi kebutuhannya, manusia membutuhkan manusia yang lainnya. Seperti halnya seseorang yang membutuh tukang kayu atau bangunan ketika ingin membangun rumah, seseorang membutuhkan penegak hukum untuk ketertiban, dan lain sebagainya.

Mengingat manusia adalah makhluk sosial seperti dijelaskan di atas, maka dapat dipahami bahwa keberadaan manusia dalam kehidupan sosial membutuhkan hukum atau aturan agar terjadi keseimbangan antara manusia sebagai individu dengan manusia sebagai mahluk sosial. Keseimbangan tersebut menciptakan adanya norma sosial dalam masyarakat.

${ }^{51}$ Miriam Budiarjo, Dasar-Dasar Ilmu Politik (Jakarta: PT Gramedia Pustaka Utama, 2008), 107.

52 Ibid.

53 Tony Hanoraga, "Dialektika Hubungan Hukum Dan Kekuasaan," Jurnal Sosial Humaniora 1, no. 1 (2008): 43-65. 
Norma sosial, dalam konteks hukum, merupakan sebuah norma yang bersumber dari aturan atau tatanan yang sudah ada di tengah-tengah masyarakat. Norma sosial memiliki cakupan yang luas dalam kajian hukum. Pertama, adat atau tradisi biasanya diartikan sebagai suatu ketentuan yang berlaku dalam masyarakat tertentu dan menjelaskan satu keseluruhan cara hidup dalam bermasyarakat. ${ }^{54}$ Dalam KBBI, tradisi mempunyai adat kebiasaan turun temurun yang masih dijalankan masyarakat. Bisa juga diartikan sebagai penilaian atau anggapan bahwa cara-cara yang telah ada merupakan cara yang paling baik dan benar. ${ }^{55}$

Kedua, sopan-santun adalah suatu peraturan yang dianggap baik dan pantas untuk dijalankan dalam kehidupan masyarakat yang muncul atau timbul dari hasil pergaulan yang dilakukan oleh sekolompok manusia yang hidup di dalam masyarakat. Sopan-santun dianggap sebagai tuntunan dan pedoman dalam kehidupan sehari-hari oleh masyarakat tersebut.

Ketiga, kebiasaan adalah sebuah tradisi yang secara terusmenerus terjadi dan berlangsung secara turun-temurun dalam masyarakat. Keberadaan kebiasaan adalah sebuah keniscayaan dalam sebuah tatanan masyarakat. Jika keberadaan kebiasaan itu tidak ada, maka akan terjadi kekacauan dalam masyarakat (chaos in society). Namun demikian, keberadaan kebiasaan tidaklah dapat bersifat absolut atau tetap. Perlu adanya fleksibilitas dalam memahami kebiasaan, sehingga kebiasaan tersebut dapat terus bisa diterima dan dijadikan pedoman oleh masyarakat. Oleh karena itu, tradisi yang kita terima perlu direnungkan kembali dan menyesuaikannya dengan perkembangan zaman. ${ }^{56}$

54 Husni Thamrin, Orang Melayu: Agama, Kekerabatan, Dan Perilaku Ekonomi (Kampar: Lembaga Penelitian dan Pengabdian kepada Masyarakat Mutu Universitas Islam Negeri Sultan Syarif Kasim, 2009), 91.

55 Departemen Pendidikan Nasional, Kamus Besar Bahasa Indonesia, 589.

${ }^{56}$ Mardimin Johanes, Jangan Tangisi Tradisi (Yogyakarta: Kanisius, 1994), 12-13. 


\section{BAB IV \\ BEBERAPA PENGERTIAN DASAR \\ DALAM HUKUM}

\subsection{Subjek Hukum}

Subjek hukum adalah segala sesuatu yang dianggap hukum memiliki hak dan kewajiban untuk melakukan perbuatan dan wewenang hukum. Dalam penjabaran yang lebih luas, subjek hukum dibagi menjadi 2 (dua), yaitu manusia dan badan hukum. ${ }^{57}$

Pertama, manusia (person). Di dalam hukum, istilah manusia berarti pembawa hak dan kewajiban. Berlakunya seseorang sebagai pembawa hak adalah mulai dari dia dilahirkan sampai meninggal dunia. Di sisi yang lain, menurut hukum, ada beberapa kualifikasi manusia yang dianggap tidak cakap dalam melaksanakan haknya, kecuali dapat diwakilkan orang lain, yaitu: (1) di bawah umur; (2) pikirannya tidak sehat atau gila; dan (3) perempuan dalam perkawinan.

Kedua, badan hukum (rechtpersoon). Selain manusia, badan hukum dapat juga memiliki hak dan kewajiban. Badan hukum itu memiliki harta kekayaan sendiri, ikut serta dalam persoalan hukum, dan dapat juga digugat atau menggugat di pengadilan dengan perantaraan pengurusnya. Badan hukum diciptakan sesuai peraturan perundang-undangan yang berlaku.

Walaupun menurut hukum setiap subjek hukum tanpa terkecuali adalah pemilik hak, tetapi tidak boleh berbuat sekehendaknya sendiri. Ada batasan tertentu dalam pelaksanaan haknya, yaitu adanya kewajiban untuk mengikuti aturan atau hukum yang telah ditetapkan.

${ }^{57}$ Lihat, Zaeni Asyhadie and Arief Rahman, Pengantar Ilmu Hukum (Jakarta: PT RajaGrafindo Persada, 2013), 61. 


\subsection{Objek Hukum}

Dalam studi hukum, selain terdapat pembahasan mengenai subjek hukum, juga terdapat objek hukum. Objek hukum dapat dipahami sebagai sesuatu yang dapat berguna bagi subjek hukum. Menurut C.S.T Kansil dan Christine S.T. Kansil, objek hukum adalah segala sesuatu yang berguna bagi subjek hukum dan yang dapat menjadi objek sesuatu perhubungan hukum. ${ }^{58}$

Dalam konteks hukum, objek hukum disebut juga dengan istilah benda. Ada benda yang berwujud, yaitu segala sesuatu yang dapat diraba oleh pancaindera, seperti rumah, buku, dan lain sebagainya. Ada juga benda tak berwujud, yaitu segala macam hak, seperti hak cipta, hak merek dagang, dan lain sebagainya.

Di dalam ketentuan yang lain, dikenal juga adanya benda bergerak dan benda tidak bergerak. Benda bergerak, yaitu bendabenda yang dapat dipindahkan, seperti buku, meja, kursi, dan lain sebagainya. Kemudian, benda tidak bergerak (benda tetap), yaitu benda-benda yang tidak dapat dipindahkan, seperti tanah dan segala yang tertanam di atasnya.

\subsection{Peristiwa Hukum}

Dalam studi hukum juga dikenal istilah peristiwa hukum atau dengan kata lain kejadian hukum (rechtsfeit). Peristiwa hukum, seperti yang dijelaskan oleh C.S.T. Kansil, adalah peristiwa-peristiwa kemasyarakatan yang oleh hukum diberikan akibat-akibat. $^{59}$

Sebagaimana keterangan di atas, dapat diambil contoh, misalnya, jika seseorang meminjam mobil, maka peminjam mempunyai kewajiban untuk mengembalikan mobil yang dipinjam. Di sisi yang lain, orang meminjami atau pemilik mobil mempunyai hak agar mobilnya dikembalikan oleh peminjam. Jadi, segala sesuatu dapat dikatakan sebagai peristiwa hukum berdasarkan pada adanya suatu kehendak dari subjek hukum yang menimbulkan hak dan kewajiban.

58 C.S.T. Kansil and Christine S.T. Kansil, Pengantar Ilmu Hukum Indonesia (Jakarta: Rineka Cipta, 2011), 101.

${ }^{59}$ Kansil, Pengantar Ilmu Hukum Dan Tata Hukum Indonesia, 121. 


\subsection{Perbuatan Hukum}

Dalam kehidupan secara individual maupun kelompok (sosial), niscaya kita melakukan aktivitas yang bersinggungan langsung dengan aturan (hukum), norma, atau nilai yang berlaku. Semua itu akan terus berlangsung demi memenuhi kepentingan kita. Aktivitas yang dimaksud, misalnya, membuat perjanjian, menikah, berwasiat, dan lain sebagainya. Aktivitas-aktivitas tersebut dapat disebut sebagai perbuatan hukum.

Dengan demikian, perbuatan hukum dapat diartikan sebagai segala bentuk perbuatan subjek hukum yang dengan sengaja dilakukan untuk menimbulkan hak dan kewajiban atas dirinya. Dapat dimungkinkan, perbuatan hukum itu sepihak, yaitu dilakukan oleh satu pihak saja dan menimbulkan hak dan kewajiban pada satu pihak pula, misalnya, membuat surat wasiat. Dapat juga perbuatan hukum itu antara 2 (dua) pihak, yaitu tentu yang dilakukan oleh 2 (dua) pihak yang menimbulkan hak dan kewajiban secara timbal balik, misalnya, perjanjian jual-beli. ${ }^{60}$

\subsection{Hubungan Hukum}

Menurut R. Soeroso, hubungan hukum adalah hubungan antara 2 (dua) atau lebih subjek hukum. Dalam hubungan hukum ini, hak dan kewajiban pihak yang satu berhadapan dengan hak dan kewajiban pihak yang lain. ${ }^{61}$ Ia menegaskan, dalam setiap hubungan hukum, terdapat pihak yang berwenang atau berhak meminta prestasi (prestatie subject) dan ada pihak yang wajib melakukan prestasi (plicht subject). ${ }^{62}$

Berkenaan dengan pendapat R. Soeroso di atas, hubungan hukum itu memiliki 3 (tiga) unsur. Pertama, adanya subjek hukum. Kedua, adanya objek hukum, misalnya, rumah. Ketiga, adanya hubungan antara pemilik hak dan pengemban kewajiban secara timbal balik.

Hubungan hukum memiliki syarat mutlak yang harus dipenuhi, sehingga apa yang dipahami dengan hubungan hukum

\footnotetext{
${ }^{60}$ Ibid., 119.

${ }^{61}$ R. Soeroso, Pengantar Ilmu Hukum (Jakarta: Sinar Grafika, 2011),
} 269.

${ }^{62}$ Ibid., 270. 
dapat katakan sebagai hubungan hukum. Pertama, adanya dasar hukum, yaitu adanya peraturan-peraturan yang telah ditetapkan yang berfungsi mengatur hubungan tersebut. Ambil contoh, misalnya, ketentuan Pasal 1474 BW tentang kewajiban menyerahkan barang yang dijual. Kedua, timbulnya suatu peristiwa hukum sebagai konsekuensi atas adanya ketentuan hukum, misalnya, peristiwa hukum berupa penyerahan barang yang dijual sebagaimana diatur oleh Pasal 1474 BW.

\subsection{Akibat Hukum}

Akibat hukum merupakan buah dari adanya suatu perbuatan atau peristiwa hukum. Dengan demikian, dalam lahirnya akibat hukum sangat berkaitan dengan kehendak yang dilakukan subjek hukum dan hukum yang diberlakukan.

Akibat hukum dapat juga dipahami sebagai sumber lahirnya suatu hak dan kewajiban bagi subjek hukum yang melakukan suatu perbuatan atau terlibat dalam peristiwa hukum. Sebagai contoh, jika seseorang melakukan perjanjian sewamenyewa, maka pada saat itu akan timbul akibat hukum dari perjanjian sewa-menyewa tersebut. Dalam perjanjian yang dimaksud, pihak yang menyewakan mempunyai hak menerima sejumlah pembayaran, sedangkan pihak penyewa mempunyai kewajiban untuk melakukan pembayaran.

Dari contoh di atas, nampak jelas bahwa perbuatan hukum yang dilakukan oleh para subjek hukum dapat menimbulkan akibat hukum. Demikian rasionalitas mengapa akibat hukum dikatakan sebagai sumber munculnya hak dan kewajiban yang dimiliki oleh subjek hukum.

\subsection{Pertanggungjawaban Hukum}

Pertanggungjawaban dalam makna yang umum adalah sebuah akibat yang diberikan atas tindakan yang telah dilakukan yang berkaitan dengan hak dan kewajiban. Sederhananya, berhak melakukan dan berkewajiban menerima akibat (tanggung jawab).

Ridwan Halim mendefinisikan tanggung jawab hukum sebagai sesuatu akibat lebih lanjut dari pelaksanaan peranan, baik peranan itu merupakan hak dan kewajiban ataupun kekuasaan. Secara umum, tanggung jawab hukum diartikan sebagai 
kewajiban untuk melakukan sesuatu atau berperilaku menurut cara tertentu yang tidak menyimpang dari peraturan yang ada. Sementara itu, Purbacaraka berpendapat, tanggung jawab hukum bersumber atau lahir atas penggunaan fasilitas dalam penerapan kemampuan tiap orang untuk menggunakan hak atau/dan melaksanakan kewajibannya. ${ }^{63}$

Dalam narasi yang berbeda, tetapi memiliki substansi yang sama, Sugeng Istanto mengemukakan, pertanggungjawaban berarti kewajiban memberikan jawaban yang merupakan perhitungan atas semua hal yang terjadi dan kewajiban untuk memberikan pemulihan atas kerugian yang mungkin ditimbulkannya. ${ }^{64}$ Dengan demikian, bentuk kewajiban yang diberikan terhadap subjek hukum adalah untuk memberikan dan menerima hak sekaligus melaksanakan dan menuntut orang lain untuk melaksanakaan kewajibannya.

\subsection{Hukum Publik dan Hukum Privat}

Dalam studi hukum, ada pengklasifikasian hukum menurut isinya, yaitu hukum privat dan hukum publik. Hukum privat mengatur hubungan-hubungan antara orang yang satu dengan orang yang lain dengan menitikberatkan kepada kepentingan perseorangan, sedangkan hukum publik mengatur hubungan antara negara dengan alat-alat perlengkapan atau hubungan antara negara dengan perseorangan. ${ }^{65}$

Yang termasuk di dalam ruang lingkup hukum privat, misalnya, hukum perdata dan hukum dagang. Di sisi yang lain, yang termasuk di dalam ruang lingkup hukum publik, misalnya, hukum tata negara (termasuk hukum administrasi negara), hukum pidana, dan hukum internasional.

Dalam segi adanya sengketa, hukum privat lebih menekankan tuntutan merupakan hak perseorangan, sehingga subjek hukum yang dirugikan dapat secara langsung mengajukan

63 Julista Mustamu, "Pertanggungjawaban Hukum Pemerintah (Kajian Tentang Ruang Lingkup Dan Hubungan Dengan Diskresi)," SASI: Jurnal Ilmiah Fakultas Hukum Universitas Pattimura Ambon 20, no. 2 (2014): 22.

64 Sugeng Istanto, Hukum Internasional (Yogyakarta: Universitas Atma Jaya, 2014), 77.

${ }^{65}$ Kansil, Pengantar Ilmu Hukum Dan Tata Hukum Indonesia, 75. 
ganti kerugian kepada subjek hukum yang dipandang melakukan pelanggaran hukum. Sementara itu, bagi hukum publik, perihal pengajuan tuntutan merupakan kewenangan negara yang diwakili oleh penuntut umum, sehingga korban tindak pidana, misalnya, tidak dapat menuntut secara langsung terduga pelaku tindak pidana. Namun, dalam perkembangannya kini, sejak munculnya konsep restorative justice, perihal menuntut yang dibedakan oleh hukum privat dan hukum publik mulai memudar garis pembedanya.

Di balik perbedaannya, hukum privat dan hukum publik sama-sama memiliki konsekuensi hukum berupa sanksi hukum yang dapat diterapkan pada keduanya. Di samping itu, keduanya juga sama-sama menjadikan hukum sebagai aturan guna mengatur keberlangsungan hidup manusia.

\subsection{Hukum yang Memaksa dan Hukum yang Mengatur}

Hukum merupakan keseluruhan aturan maupun kaidah yang berlaku dalam suatu kehidupan bersama yang mengatur mengenai tingkah laku yang dalam pelaksanaannya dapat dipaksakan dengan hadirnya suatu sanksi. ${ }^{66}$ Artinya, hukum itu mempunyai sifat yang mengatur secara mutlak berikut juga dimungkinkan memuat sifat memaksa dengan menghadirkan sebuah sanksi.

Hukum yang mengatur adalah hukum yang dapat dikesampingkan apabila pihak-pihak yang bersangkutan telah membuat peraturan sendiri dalam suatu perjanjian. ${ }^{67}$ Contohnya adalah hukum dagang. Di dalam melakukan sebuah transaksi, antara penjual dan pembeli dapat mengesampingkan standar aturan jual-beli yang ada jika antara keduanya telah melakukan kesepakatan yang lain dalam transaksinya. Namun, tetap ada aturan yang diberlakukan.

Hukum yang memaksa adalah hukum yang dalam keadaan bagaimanapun juga harus mempunyai paksaan mutlak. ${ }^{68}$ Contohnya adalah hukum pidana. Di dalam sebuah pelanggaran

\footnotetext{
66 Ibid., 38.

${ }^{67}$ Ibid., 75.

${ }^{68}$ Ibid.
} 
di dalam kasus pidana, apapun alasannya, jika telah terbukti melakukan pelanggaran sesuai alat bukti yang sah, maka subjek hukum yang telah melanggar dapat dikenai sanksi sesuai peraturan perundangan-undangan yang berlaku. 


\section{BAB V \\ BEBERAPA ASAS DALAM HUKUM}

\subsection{Pengertian Asas Hukum}

Menurut KBBI, asas adalah dasar. Dalam beberapa referensi, asas adalah pikiran dasar yang bersifat umum yang menjadi latar belakang bagi lahirnya sistem hukum dalam peraturan perundang-undangan dan putusan hakim yang merupakan hukum positif dengan sifat-sifat dalam peraturan yang konkrit. Dengan kata lain, asas hukum merupakan aturan dasar dan prinsip-prinsip hukum yang abstrak dan pada umumnya melatarbelakangi peraturan konkrit dan pelaksanaan hukum. ${ }^{69}$

Apabila kita sampai pada pembicaraan mengenai asas hukum, maka pada saat itu kita membicarakan unsur yang penting dan pokok dari peraturan hukum. Barangkali tidak berlebihan apabila dikatakan bahwa asas hukum ini merupakan "jantungnya" peraturan hukum. Kita menyebutnya demikian, karena merupakan landasan yang paling luas bagi lahirnya suatu peraturan hukum. Ini berarti, peraturan-peraturan hukum itu pada akhirnya bisa dikembalikan kepada asas tersebut. Asas hukum ini tidak akan habis kekuatannya dengan melahirkan suatu peraturan hukum, melainkan akan tetap saja ada dan akan melaksanakan peraturan-peraturan selanjutnya. ${ }^{70}$

Dalam bahasa Inggris, kata "asas" diformatkan sebagai "principle". Konsekuensinya, peraturan konkrit, seperti undangundang, tidak boleh bertentangan dengan asas-asas hukum. Begitu juga dalam putusan hakim, pelaksanaan hukum, dan hukum dasar. Dengan demikian, asas hukum adalah prinsip yang dianggap dasar atau fundamental dalam hukum.

${ }^{69}$ Asyhadie and Rahman, Pengantar Ilmu Hukum, 135.

${ }^{70}$ Rahardjo, Ilmu Hukum, 45. 
Beberapa pakar hukum memberikan pendapat mengenai apa itu asas hukum, yaitu sebagai berikut: ${ }^{71}$

- Menurut Bellefroid, asas hukum adalah norma dasar yang dijabarkan dari hukum positif dan yang oleh ilmu hukum tidak dianggap berasal dari aturan-aturan yang lebih umum tersebut. Asas hukum umum itu lebih kepada pengendapan hukum positif dalam suatu masyarakat.

- Menurut P. Scholten, asas hukum ialah kecenderungankecenderungan yang diisyaratkan oleh pandangan kesusilaan kita pada hukum yang merupakan sifat-sifat umum dengan segala keterbatasannya sebagai pembawaan yang umum, tetapi yang tidak boleh tidak harus ada.

- Menurut Van Eikema Hommes, asas hukum itu tidak boleh dianggap sebagai norma-norma hukum yang konkrit, tetapi perlu dianggap sebagai dasar-dasar umum atau petunjukpetunjuk bagi hukum yang berlaku tersebut. Pembentukan hukum praktis itu perlu berorientasi pada asas-asas hukum tersebut. Dengan kata lain, ia merupakan dasar-dasar atau petunjuk arah dalam pembentukan hukum positif.

- Menurut Satjipto Rahardjo, asas hukum adalah unsur yang penting dan pokok dari peraturan hukum. Asas hukum merupakan jantung dari peraturan hukum, karena ia adalah landasan yang paling luas bagi lahirnya peraturan hukum.

\subsection{Beberapa Asas dalam Hukum}

Sejatinya, ada banyak sekali asas dalam hukum. Namun, ada beberapa asas yang dinilai penting atau sering kita dengar, di antaranya adalah sebagai berikut:

- Asas persamaan di muka hukum (equality before the law). Artinya, setiap orang harus diperlakukan sama di muka hukum tanpa membedakan suku, agama, ras, pangkat, jabatan, dan sebagainya.

- Asas legalitas. Artinya, tidak ada suatu perbuatan yang dapat dihukum sebelum didahului oleh suatu peraturan atau undang-undang yang mengaturnya. ${ }^{72}$

${ }^{71}$ Asyhadie and Rahman, Pengantar Ilmu Hukum, 135-136. 
- Asas nonretro aktif (tidak berlaku surut). Artinya, sebuah peraturan tidak dapat dikenakan pada kejadian sebelum peraturan disahkan sesuai dengan asas legalitas. ${ }^{73}$

- Asas ius curia novit (hakim dianggap tahu hukum). artinya, hakim tidak boleh menolak untuk mengadili dan memutus perkara dengan alasan tidak ada hukumnya atau tidak tahu dasar hukumnya.

- Asas unus testis nullus testis (satu saksi bukan saksi). Artinya, saksi yang hanya satu orang dalam suatu kasus, tidak dapat dinilai sebagai saksi.

- Asas fiksi hukum, yaitu semua orang dianggap tahu hukum. Apabila suatu undang-undang, misalnya, telah diundangkan dalam lembaran negara, maka dianggap telah diketahui oleh masyarakat, sehingga tidak ada alasan bagi yang melanggar.

- Asas lex specialis derogate legi generalis. Artinya, hukum yang khusus lebih diutamakan dari hukum yang umum. Ketentuan umum dapat dikesampingkan oleh ketentuan khusus yang mengatur hal yang sama.

- Asas lex superior derogate legi inferiori. Artinya, hukum yang tinggi lebih diutamakan pelaksanaan dari pada hukum yang rendah.

- Asas lex posterior derogate legi priori. Artinya, peraturan yang baru didahulukan dari pada peraturan yang lama.

- Asas presumption of innocence (praduga tak bersalah). Artinya, seseorang tidak boleh dianggap bersalah sebelum dibuktikan kesalahannya melalui putusan hakim yang berkekuatan hukum tetap. ${ }^{74}$

- Asas in dubio pro ore. Artinya, apabila hakim mengalami keraguan dalam menjatuhkan sanksi terhadap terdakwa, maka

${ }^{72}$ Lihat selengkapnya, Moch Choirul Rizal, Buku Ajar Hukum Pidana (Kediri: Lembaga Studi Hukum Pidana, 2021), 67-73.

${ }^{73}$ Lihat selengkapnya, Ibid., 76-78.

${ }^{74}$ Lihat selengkapnya, Moch Choirul Rizal, Diktat Hukum Acara Pidana (Kediri: Fakultas Syariah IAIN Kediri, 2021), 7-8. 
hakim menjatuhkan sanksi yang paling meringankan bagi terdakwa.

- Asas pacta sunt servanda (janji itu mengikat). Artinya, suatu perjanjian berlaku sebagai undang-undang bagi para pihak yang membuatnya. 


\section{BAB VI \\ BERBAGAI SISTEM HUKUM DI DUNIA}

\subsection{Pengertian Sistem Hukum}

Membicarakan hukum sebagai suatu sistem, sebaiknya kita mulai dari pembicaraan tentang sistem itu sendiri. Karena bagaimanapun, hukum sebagai suatu sistem akan tunduk pada batasan dan ciri-ciri sistem juga. Sistem merupakan jenis satuan yang mempunyai tatanan tertentu. Sistem memuat suatu struktur yang tersusun dari bagian-bagian. Sistem merupakan suatu rencana metode atau prosedur untuk mengerjakan sesuatu. ${ }^{75}$

Lebih lanjut, sistem hukum merupakan kesatuan utuh dari tatanan-tatanan yang terdiri atas unsur-unsur, seperti peraturan, peradilan, pelaksana hukum, dan partisipasi masyarakat yang satu sama lain saling berhubungan untuk mencapai tujuan agar tidak terjadi konflik dan kontradiksi. Namun, ia merupakan sistem yang abstrak dan terbuka. Artinya, sistem hukum itu terdiri dari unsur-unsur yang tidak konkrit, tidak menunjukkan kesatuan yang dapat dilihat, mempunyai hubungan timbal-balik dengan lingkungannya, dan unsur-unsur lain yang tidak termasuk dalam sistem yang mempunyai pengaruh terhadap unsur-unsur dalam sistem. ${ }^{76}$

\subsection{Sistem Hukum Eropa Kontinental (Civil Law System)}

Sistem yang dianut oleh negara-negara Eropa kontinental yang didasarkan atas hukum Romawi disebut sebagai civil law system. Disebut demikian, karena hukum Romawi pada mulanya bersumber kepada karya Kaisar Iustinianus, yaitu Corpus Iuris Civilis. ${ }^{77}$ Kumpulan berbagai kaidah hukum, baik yang ada sebelum maupun saat masa Iustianus tersebut, dijadikan prinsip

${ }^{75}$ Rahardjo, Ilmu Hukum, 48.

${ }^{76}$ Asyhadie and Rahman, Pengantar Ilmu Hukum, 155.

${ }^{77}$ Marzuki, Pengantar Ilmu Hukum, 223. 
dasar dalam perumusan dan kodifikasi hukum di negara-negara Eropa daratan. Prinsip utamanya bahwa hukum itu memperoleh kekuatan mengikat, karena berupa peraturan yang berbentuk undang-undang yang tersusun secara sistematis dalam kodifikasi. $^{78}$

Sumber hukum utama negara yang menganut civil law system adalah undang-undang yang dibentuk oleh badan legislatif. Dalam hal ini, hakim tidak bebas dalam menciptakan hukum baru, karena hakim hanya menerapkan dan menafsirkan peraturan yang ada padanya. Putusan hakim tidak mengikat umum, tetapi hanya mengikat para pihak yang berperkara saja. Negara-negara yang menganut sistem ini, di antaranya, Prancis, Belanda, dan juga Indonesia. ${ }^{79}$

\subsection{Sistem Hukum Common Law (Anglo-Saxon)}

Sistem hukum Anglo-Saxon mula-mula berkembang di negara Inggris yang didasarkan atas hukum asli rakyat Inggris. ${ }^{80}$ Dikenal pula dengan istilah rule of law, common law, unwritten law, atau sering disebut juga dengan istilah case law. Sistem hukum ini didasarkan pada yurisprudensi, yaitu putusan-putusan hakim terdahulu yang kemudian menjadi dasar putusan hakimhakim selanjutnya. Dengan begitu, hakim mempunyai wewenang yang luas untuk menafsirkan peraturan-peraturan hukum dan menciptakan prinsip-prinsip hukum baru yang berguna sebagai pegangan bagi hakim-hakim lain dalam memutuskan perkara sejenis. $^{81}$

Bagi sebagian ahli hukum, penerapan common law system lebih mudah, terutama pada masyarakat pada negara-negara berkembang, karena sesuai dengan perkembangan zaman. Dalam hal ini, pendapat para ahli dan prakitisi hukum lebih menonjol digunakan oleh hakim dalam memutus perkara. Sistem hukum ini

78 AK and Partners, "Macam-Macam Sistem Hukum Di Dunia," accessed September 10, 2021, https://kantorhukum-akp.com/berita-macammacam-sistem-hukum-di-dunia.

79 Ibid.

${ }^{80}$ Marzuki, Pengantar Ilmu Hukum, 223.

${ }^{81}$ AK and Partners, "Macam-Macam Sistem Hukum Di Dunia." 
dianut di negara-negara anggota persemakmuran Inggris, Amerika Utara, Kanada, dan Amerika Serikat. ${ }^{82}$

\subsection{Sistem Hukum Adat ${ }^{83}$}

Asal mula istilah hukum adat adalah dari istilah "adatrecht" yang dikemukakan oleh Snouck Hurgronye. Sumber utama sistem hukum adat adalah hukum tidak tertulis atau kebiasaan. Sifat hukum adat adalah tradisional dengan berpangkal pada kehendak nenek moyang. Tolak ukurnya adalah kehendak suci dari nenek moyangnya. Pemuka adat mempunyai peran dalam menjalankan sistem hukum adat, mengingat ia adalah sosok yang disegani oleh masyarakat.

Sistem hukum adat juga dapat diartikan sebagai seperangkat norma dan aturan adat (kebiasaan) yang berlaku di suatu wilayah tertentu. Sistem hukum adat terdapat dan berkembang di lingkungan kehidupan sosial, di antaranya, di Indonesia, Republik Rakyat Tiongkok, India, dan Jepang. Di Indonesia, sistem hukum adat diadopsi dalam bentuk subsistem hukum, yaitu hukum adat.

\subsection{Sistem Hukum Islam $^{84}$}

Sistem hukum Islam berasal dari Arab, kemudian berkembang ke negara-negara Asia, Afrika, Eropa, dan Amerika secara individual maupun secara kelompok. Sistem hukum Islam bersumber pada: (1) al-Qur'an yang merupakan kitab suci agama Islam; (2) sunnah yang merupakan cerita atau cara hidup nabi; (3) 'ijma yang merupakan kesepakatan para ulama besar; dan (4) qiyas yang merupakan analogi dalam mencari sebanyak mungkin persamaan antara 2 (dua) kejadian.

Beberapa ciri khas sistem hukum Islam yang membedakan dengan sistem hukum yang lain, di antaranya: (1) bersumber pada wahyu Allah SWT (al-Qur'an), sunnah Rasul, dan ijtihad ulama; (2) ketentuan-ketentuannya didasarkan pada akhlak dan agama; (3) sanksi terhadap pelanggarannya adalah

${ }^{82}$ Ibid.
${ }^{83}$ Ibid.
${ }^{84}$ Ibid. 
rangkap, yaitu sanksi di dunia dan akhirat; dan (4) tujuannya agar masyarakat tenteram dunia dan akhirat.

\subsection{Sistem Hukum Kanonik ${ }^{85}$}

Sistem hukum kanonik adalah sistem hukum yang dianut oleh negara-negara yang tunduk kepada peraturan-peraturan gereja. Kitab hukum kanonik terdiri dari 7 (tujuh) buku: (1) Buku I memuat tentang norma-norma umum; (2) Buku II memuat tentang umat Allah; (3) Buku III memuat tentang tugas mengajar gereja; (4) Buku IV memuat tentang tugas gereja menguduskan; (5) Bab V memuat tentang harta benda duniawi gereja; (6) Buku VI memuat tentang hukuman-hukuman dalam gereja atau sanksi dalam gereja; dan (7) Buku VII memuat tentang proses atau hukum acara.

\subsection{Sistem Hukum Sosialis ${ }^{86}$}

Sistem hukum sosialis adalah nama resmi untuk sistem hukum di negara-negara komunis. Sistem hukum ini berasal dari hukum Uni Soviet yang dikembangkan sejak tahun 1971. Quigley menggambarkan, sistem hukum sosialis sebagai hukum negaranegara yang pemerintahnya secara resmi melihat negara sebagai salah satu sosialis atau bergerak dari kapitalisme ke sosialisme dan yang memegang teguh masyarakat komunistik sebagai sebuah tujuan akhir.

Pokok ajaran sistem hukum sosialis adalah hukum yang dijiwai ajaran "Marxist-Leninist" yang dianut oleh para pakar hukum di Uni Soviet. Berikut juga ajaran materialisme dan teori evolusi yang berpendapat bahwa materi merupakan satu-satunya benda nyata di dunia ini. Negara-negara yang menganut sistem hukum ini hanya mengenal konsep hukum publik. Artinya, konsep hukum privat tidak ada.

Sumber hukum dalam sistem hukum sosialis adalah keputusan tertinggi para penguasa berupa produk kebijaksanaan pemerintah atau negara. Tidak ada sumber hukum yang resmi, melainkan hukum adalah penguasa negara dan hukum membela rakyat proletar (masyarakat kelas sosial rendah). Hukum sosialis

\footnotetext{
85 Ibid.

${ }^{86}$ Ibid.
} 
lebih bersifat prerogatif ketimbang normatif. Contoh negara penganut hukum sosialis, di antaranya, Korea Utara, China, dan Kuba. 


\section{BAB VII \\ SUMBER-SUMBER HUKUM}

\subsection{Pengertian Sumber Hukum}

Hukum berkaitan erat dengan kepastian. Hukum hendak menciptakan kepastian dalam mengatur hubungan antara orangorang yang ada di dalam masyarakat. Masalah kepastian hukum tersebut berkaitan erat dengan masalah dari mana hukum itu berasal.

Sumber hukum adalah tempat di mana kita dapat menemukan hukum. Merupakan dasar berlakunya kekuatan hukum, sehingga dapat digunakan sebagai peraturan yang ditaati masyarakat. Menurut KBBI, sumber adalah segala sesuatu yang berupa tulisan, dokumen, naskah, dan sebagainya yang digunakan oleh suatu bangsa sebagai pedoman hidupnya pada masa tertentu.

Menurut C.S.T. Kansil, sumber hukum adalah segala apa saja yang menimbulkan aturan-aturan yang mempunyai kekuatan yang bersifat memaksa, yaitu aturan-aturan yang kalau dilanggar mengakibatkan sanksi yang tegas dan nyata. ${ }^{87}$ Jadi, sumber hukum adalah tempat untuk melihat perwujudan hukum yang memiliki kekuatan mengikat. Dengan demikian, perlu untuk memperhatikan faktor-faktor yang dapat mempengaruhi hukum, seperti dari mana hukum ditemukan dan berdasarkan norma apa hukum tersebut. ${ }^{88}$

\subsection{Sumber Hukum Materiil}

Sumber hukum materiil merupakan sumber dari mana materi hukum diambil. Sumber hukum ini menjadi faktor-faktor yang menentukan isi atau materi hukum yang memiliki kaitan

${ }^{87}$ Kansil, Pengantar Ilmu Hukum Dan Tata Hukum Indonesia, 46.

88 Dzawi Kafa Nilla, "Mengenal Sumber Hukum: Sejarah Dan Jenisnya," Heylaw Edu, last modified 2021, accessed September 10, 2021, https://heylawedu.id/blog/mengenal-sumber-hukum-sejarah-dan-jenisnya. 
erat dengan keyakinan dari tiap individu maupun pendapat umum yang dapat menentukan isi sebuah hukum. Sederhananya, sumber hukum materiil itu melihat dari segi isi sebuah hukum. Misalnya, KUHP yang mengatur mengenai pidana umum, kejahatan, dan pelanggaran, atau KUHPerdata yang mengatur mengenai masalah individu dengan sesamanya, perikatan, perjanjian, pembuktian, daluarsa, dan lain sebagainya. ${ }^{89}$

Keyakinan hukum individu (anggota masyarakat) dan pendapat hukum (legal opinion) dapat menjadi sumber hukum materiil. Selain itu, sumber hukum materiil bisa juga berupa halhal yang mempengaruhi pembentukan hukum, seperti pandangan hidup, hubungan sosial dan politik, situasi ekonomi, corak, peradaban (agama dan kebudayaan), serta letak geografis dan konfigurasi internasional. Contoh sumber hukum materiil adalah agama, kesusilaan, kehendak Tuhan, akal budi, hubungan sosial, dan lain sebagainya.

\subsection{Sumber Hukum Formil}

Sumber hukum formil adalah sumber hukum dengan bentuk tertentu yang merupakan dasar berlakunya hukum secara formal. Ia merupakan sumber hukum yang dikenal dan digali dalam bentuk peraturan. Merujuk pada bentuknya, sumber hukum formil diketahui dan ditaati, sehingga memperoleh kekuatan hukum. Dengan demikian, selama belum mempunyai bentuk, maka suatu hukum baru hanya merupakan perasaan hukum atau cita-cita hukum yang belum mempunyai kekuatan mengikat. Oleh karena itu, sumber hukum formil membentuk pandanganpandangan hukum menjadi aturan-aturan hukum dan mengikat. ${ }^{90}$

Sumber-sumber hukum formil, di antaranya adalah sebagai berikut:

- Peraturan perundang-undangan. Sumber hukum formil ini merupakan peraturan-peraturan tertulis yang dibuat oleh alat perlengkapan negara yang berwenang dan mengikat setiap orang.

${ }^{89}$ Asyhadie and Rahman, Pengantar Ilmu Hukum, 88.

${ }^{90}$ Ibid., 88-89. 
- Yurisprudensi. Sumber hukum formil ini berisi putusanputusan hakim terdahulu dalam menghadapi suatu perkara yang kemudian dijadikan sebagai pedoman bagi hakim lain untuk menyelesaikan perkara yang serupa. Yurisprudensi ada karena terdapat ketidakjelasan hukum yang mengatur sebelumnya, sehingga menyulitkan hakim untuk membuat sebuah keputusan.

- Perjanjian. Sumber hukum formil ini berasal dari suatu peristiwa antara pihak yang satu dengan pihak yang lain untuk melaksanakan sesuatu atau tidak melaksanakan sesuatu, sehingga pihak-pihak yang tersebut terikat oleh isi perjanjian yang mereka buat.

- Traktat. Sumber hukum formil ini dapat disebut juga sebagai perjanjian antarnegara, yaitu suatu perjanjian internasional antar 2 (dua) negara atau lebih. Traktat merupakan sumber hukum karena mengikat negara-negara yang melakukan perjanjian.

- Kebiasaan. Dalam hal ini, semua aturan yang tidak ditetapkan oleh negara, tetapi ditaati oleh masyarakat karena suatu keyakinan tertentu, maka dapat berlaku sebagai hukum. Dengan kata lain, perbuatan subjek hukum yang dilakukan secara berulang-ulang mengenai hal yang sama dan diterima oleh masyarakat luas, maka dapat dipandang sebagai hukum tidak tertulis.

- Doktrin. Sumber hukum formil ini memuat pendapat para ahli hukum terkemuka dan mendapat pengakuan masyarakat. Doktrin berkaitan erat dengan yurisprudensi. Hakim dalam memutus sebuah perkara, misalnya, seringkali mengutip pendapat para ahli hukum yang dipandang memiliki kemampuan dalam persoalan yang ditanganinya. 


\section{BAB VIII \\ BEBERAPA ALIRAN DALAM HUKUM}

Belum ada paradigma di dalam ilmu pengetahuan hukum yang berhasil mengklaim dirinya sebagai kebenaran abadi. ${ }^{91}$ Paradigma hukum yang lahir lebih baru merupakan kritik terhadap paradigma hukum yang lahir sebelumnya yang dipandang tidak lagi memadai untuk menjawab persoalan di masyarakat. Siklus yang demikian akan terus terjadi pada kemudian hari.

\subsection{Aliran Hukum Kodrat atau Hukum Alam}

Aliran hukum ini telah ada sejak zaman dahulu. Pernah diajarkan oleh Aristoteles. ${ }^{92}$ Kriterium kebenaran dalam aliran hukum kodrat atau hukum alam dipandang berasal dari kaidahkaidah petunjuk Illahi, seperti yang dinaskahkan dalam kitab suci. Kekuatan hukum kodrat menuntut agar hukum positif yang dibuat oleh manusia selalu dipertanggungjawabkan validitasnya pada prinsip-prinsip. ${ }^{93}$

Gagasan mengenai hukum alam didasarkan pada asumsi bahwa melalui penalaran, hakikat makhluk hidup akan dapat diketahui dan pengetahuan tersebut menjadi dasar tertib sosial serta tertib hukum eksistensi manusia. Hukum alam dianggap lebih tinggi dari hukum yang sengaja dibentuk oleh manusia. ${ }^{94}$ berikut: ${ }^{95}$

Thomas Aquinas (1225-1274) membagi hukum sebagai

${ }^{91}$ Putro, Kritik Terhadap Paradigma Positivisme Hukum, 80.

92 Endrik Safudin, Pengantar Ilmu Hukum (Malang: Setara Press, 2020), 101.

93 Theo Huijbers, Filsafat Hukum Dalam Lintasan Sejarah (Yogyakarta: Kanisius, 2008), 39-40.

${ }^{94} \mathrm{AZ}$ and Yahyanto, Pengantar Ilmu Hukum (Sejarah, Pengertian, Konsep Hukum, Aliran Hukum, Dan Penafsiran Hukum), 94.

${ }^{95}$ Lihat, Huijbers, Filsafat Hukum Dalam Lintasan Sejarah, 39-40. 
- Lex aeterna, yaitu hukum abadi yang menguasai seluruh dunia yang bersumber dari rasio Tuhan dan menjadi dasar bagi semua hukum yang ada.

- Lex divina, yaitu bagian dari rasio Tuhan yang bisa ditangkap atas dasar wahyu yang difirmankan.

- Lex natauralis, yaitu merupakan perwujudkan lex aeterna pada rasio manusia untuk dapat melakuakn suatu penilaian dalam menentukan mana yang baik dan buruk.

- Lex positivis, yaitu memuat tentang hukum yang berlaku yang bersumber dari kitab-kitab suci dan buatan manusia.

Dalam kerangka pemikiran Thomas Aquinas, lex positivis tidak boleh bertentangan dengan lex naturalis dan lex devina. Hukum dan moral saling bertautan dan tidak dapat dipisahkan. Bahkan, kedudukan moral lebih tinggi dibanding hukum positif, yaitu suatu hukum positif hanya sah sejauh sesuai dengan prinsipprinsip moral dan firman tuhan. ${ }^{96}$

\subsection{Aliran Positivisme Hukum atau Legisme}

Aliran positivisme hukum atau legisme memandang, hukum itu identik dengan undang-undang, karena memberikan kepastian hukum dari setiap permasalahan di tengah-tengah masyarakat. Aliran ini memisahkan secara tegas antara hukum dan moral. Oleh karena itu, tidak ada hukum yang lain kecuali perintah penguasa (law is a command of the lawgivers). ${ }^{97}$

Aliran positivisme terbelah menjadi 2 (dua). Pertama, aliran hukum positif analitis (analytical jurisprudence). Dalam pandangan aliran ini, hukum merupakan perintah dari penguasa negara. Ia dipandang sebagai suatu sistem yang tetap, logis, dan tertutup. Menurut John Austin (1790-1850), hukum itu meliputi adanya penguasa (sovereignty), suatu perintah (command), kewajiban untuk menaati (duty), dan sanksi bagi mereka yang tidak taat (sanction). ${ }^{98}$

\footnotetext{
96 Putro, Kritik Terhadap Paradigma Positivisme Hukum, 83.

${ }^{97}$ Safudin, Pengantar Ilmu Hukum, 109.

98 Ibid.
} 
Kedua, aliran hukum murni (reine rechtslehre). Menurut Hans Kelsen (1881-1971), hukum harus dibersihkan dari anasiranasir yang nonyuridis. Hukum tidak mempersoalkan "bagaimana hukum itu seharusnya", melainkan "apa hukumnya". Oleh karena itu, yang dipakai adalah hukum positif (ius constitutum), bukan yang dicita-citakan (ius constituendum). ${ }^{99}$

\subsection{Aliran Utilitarianisme}

Menurut aliran ini, baik buruk atau adil tidaknya suatu hukum bergantung kepada apakah hukum itu memberikan kebahagiaan kepada manusia atau tidak. Menurut Jeremy Bentham (1748-1832), semua tindakan manusia diarahkan pada upaya untuk memaksimalkan kesenangan (happiness) dan meminimalkan kesusahan (pain). ${ }^{100}$

Ikhtisar ajaran Jeremy Bentham mengenai aliran ini, pertama, tujuan hukum dan wujud keadilan adalah untuk kebahagiaan yang sebesar-besarnya untuk sebanyak-banyaknya orang. Kedua, tujuan perundang-undangan adalah untuk menghasilkan kebahagiaan bagi masyarakat. Untuk itu, perundang-undangan harus berusaha untuk mencapai tujuan memberi nafkah hidup, memberikan makanan yang berlimpah, memberikan perlindungan, dan mencapai persamaan. ${ }^{101}$

Aliran utilitarianisme ini dipandang dapat sinergi dengan peranan hukum yang modern, yaitu sebagai penjaga keseimbangan dari berbagai macam kepentingan (balance of interest). Namun, di sisi yang lain, konsep mengenai kebahagiaan individu secara otomatis akan mewujudkan kebahagiaan masyarakat dipandang terlalu sederhana dan tidak realistis, karena dalam kenyataannya tidak semudah itu. ${ }^{102}$

${ }^{99}$ Ibid., 110-111.

${ }^{100}$ Ibid., 111-112.

101 Bernard L. Tanya, Yoan N. Simanjuntak, and Markus Y. Hage, Teori Hukum: Strategi Tertib Manusia Lintas Ruang Dan Generasi (Yogyakarta: Genta Publishing, 2010), 267.

102 AZ and Yahyanto, Pengantar Ilmu Hukum (Sejarah, Pengertian, Konsep Hukum, Aliran Hukum, Dan Penafsiran Hukum), 108. 


\subsection{Aliran Sejarah atau Mazhab Sejarah}

Aliran sejarah atau mazhab sejarah timbul sebagai reaksi terhadap para pemuja hukum alam. ${ }^{103}$ Berkembang di negaranegara penganut common law system. ${ }^{104} \mathrm{Jantung}$ aliran ini adalah hukum itu tidak dibuat, melainkan tumbuh bersama dengan masyarakat secara organis. ${ }^{105}$

Menurut Friederich Karl von Savigny (1779-1861), setiap bangsa memiliki kesadaran hukum, kebiasaan, dan budaya yang berbeda dengan bangsa yang lain yang dapat ditemukan dalam jiwa bangsa (volksgeist) yang bersifat unik, tertinggi, dan realitas mistis. ${ }^{106}$ Oleh karena itu, hukum berlainan dan berubah sesuai dengan tempat dan zaman. ${ }^{107}$

Ciri khas aliran ini adalah ketidakpercayaannya kepada pembuatan undang-undang dan kodifikasi. ${ }^{108}$ Mengingat ciri tersebut, aliran ini sesungguhnya juga "menyerang" aliran positivisme hukum dengan menyatakan bahwa hukum bukan hanya yang dikeluarkan oleh penguasa yang sah dalam bentuk undang-undang. Hukum juga sesungguhnya merupakan volksgeist dan substansinya adalah aturan tentang kebiasaan hidup masyarakat.

\subsection{Aliran Hukum Bebas (Freirechtslehre)}

Aliran penentang paling keras terhadap aliran positivisme hukum. Lahir sekira tahun 1906 di Jerman. Merupakan sintesis dari proses dialektika antara ilmu hukum analitis dan sosiologis. Di antara tokohnya adalah Herman Isay, Stampe, dan Fuch.

Tujuannya memberikan peradilan sebaik-baiknya dengan cara memberi kebebasan kepada hakim tanpa terikat dengan undang-undang, melainkan menghayati tata kehidupan seharisehari. Hal tersebut membuktikan bahwa di dalam undang-

${ }^{103}$ Safudin, Pengantar Ilmu Hukum, 106.

104 AZ and Yahyanto, Pengantar Ilmu Hukum (Sejarah, Pengertian,

Konsep Hukum, Aliran Hukum, Dan Penafsiran Hukum), 108.

105 Syarifin, Pengantar Ilmu Hukum, 96.

106 Putro, Kritik Terhadap Paradigma Positivisme Hukum, 87.

107 Syarifin, Pengantar Ilmu Hukum, 96.

108 AZ and Yahyanto, Pengantar Ilmu Hukum (Sejarah, Pengertian, Konsep Hukum, Aliran Hukum, Dan Penafsiran Hukum), 109. 
undang terdapat kekurangan-kekurangan dan kekurangan tersebut perlu untuk dilengkapi. ${ }^{109}$

Aliran ini menegaskan bahwa hakim mempunyai tugas menciptakan hukum, bukan hanya menerapkan undangundang. ${ }^{110}$ Dengan demikian, yurisprudensi merupakan hal yang penting dan dianggap primer, sedangkan undang-undang merupakan hal yang sekunder. ${ }^{111}$ Dalam konteks Indonesia, perkembangan aliran hukum ini belum begitu terlihat. Hal ini mengingat masih kuatnya cengkraman akan dominasi kaum positivisme hukum.

\subsection{Aliran Realisme Hukum}

Di antara tahun 1895 sampai dengan 1937, hakim di Amerika Serikat mengasumsikan bahwa hukum adalah objektif dan kedap dari persoalan sosial. Cara pandang formalistik demikian mendapat kritik dari Karl Llewellyn yang menerbitkan esai berjudul "A Realistic Jurisprudence - The Next Step" yang terbit pada tahun 1930. Pun, oleh Jerome Frank menulis "Law and The Modern Mind" yang terbit pada tahun 1930 yang mengkritik cara pandang formalistik sebagai khayalan tentang hukum dan pengadilan. Keduanya termasuk sebagai kaum realis. $^{112}$

Kaum realis mendasarkan pemikirannya pada konsepsi radikal tentang proses peradilan. Dalam hal ini, hakim lebih pantas disebut "membuat" dari pada sekedar "menemukan" hukum. ${ }^{113}$ Mengingat dasar pemikiran tersebut, aliran realisme hukum berpendapat bahwa hakim selayaknya menjadikan faktafakta sebagai patokan, bukan undang-undang. Dengan demikian, hakim membuat suatu kekeliruan ketika menerapkan hukum yang sama pada situasi fakta yang berbeda. ${ }^{114}$

${ }^{109}$ Ibid., 121.

110 Safudin, Pengantar Ilmu Hukum, 116.

111 Syarifin, Pengantar Ilmu Hukum, 98.

112 Putro, Kritik Terhadap Paradigma Positivisme Hukum, 89.

113 Rachmad Baro, Teori Hukum (Makassar: Lephaer Unkhair dan Intan Cendekia, 2005), 275.

114 Putro, Kritik Terhadap Paradigma Positivisme Hukum, 90. 
Secara epistemologis, pemikiran realisme hukum dipengaruhi pragmatisme, yaitu sebuah filsafat yang dikembangkan John Dewey dan William James yang tumbuh subur di Amerika Serikat. Konsekuensinya, aliran realisme hukum lebih percaya pada pengalaman daripada yang diperoleh dari logika dan konsep yang abstrak. ${ }^{115}$

Aliran ini terbelah menjadi 2 (dua). Pertama, aliran the sociological of wing of realism. Menurut aliran ini, putusan pengadilan dapat diprediksikan sesuai fakta. Oleh karena itu, kekuatan sosial mempengaruhi para hakim. Kedua, aliran the indiosyncracy wing of realism. Menurut aliran ini, personalitas dari hakim adalah faktor yang sangat penting dalam pengelolaan hukum. ${ }^{116}$

\subsection{Aliran Sociological Jurisprudence}

Aliran ini menganggap perintah penguasa serta hukum yang timbul dan berkembang bersama dengan masyarakat adalah sama pentingnya. Mengingat anggapan tersebut, aliran ini timbul dari proses dialektika antara (tesis) positivisme hukum dan (antitesis) mazhab sejarah hukum. ${ }^{117}$

Aliran ini memandang hukum sebagai kenyataan sosial. Mengingat pandangan tersebut, hukum merupakan hasil interaksi sosial dalam kehidupan di masyarakat. Hukum adalah gejala masyarakat, karenanya perkembangan hukum sesuai dengan perkembangan masyarakat, baik timbul, berubah, maupun lenyapnya. ${ }^{118}$

Menurut Eugen Ehrlich (1862-1922), hukum positif baru akan memiliki daya berlaku efektif apabila berisikan atau selaras dengan hukum yang hidup dalam masyarakat. Sementara itu, menurut Roscoe Pound (1870-1964), hukum berfungsi sebagai alat untuk memperbarui masyarakat dalam rangka menata

\footnotetext{
115 Ibid., 92.

116 Ibid., 91.

117 Safudin, Pengantar Ilmu Hukum, 112-113.

118 Titik Triwulan Tutik, Pengantar Ilmu Hukum (Jakarta: Prestasi
} Pustaka Publisher, 2006), 156. 
perubahan (law is a tool of social engineering). Untuk itu, hukum harus melindungi kepentingan umum, sosial, dan pribadi. ${ }^{119}$

\subsection{Aliran Marxist Theory of Law}

Karl Marx menegaskan, hukum dibuat sebagai alat "the ruling class" untuk menekan atau menindas "the ruled class". Oleh karena itu, isu utama dalam bukanlah keadilan, karena ia tidak lebih dari sarana penguasaan dan piranti para pengeksploitasi yang menggunakannya sesuai kepentingan mereka. ${ }^{120}$

Dalam positivisme hukum, subjek hukum dinyatakan telah melakukan tindak pidana pencurian apabila memenuhi unsur-unsur dalam pasal yang mengaturnya. Di sisi yang lain, aliran marxist theory of law akan menelusuri hakikat "eksploitasi" dalam kasus pencurian tersebut. ${ }^{121}$

\subsection{Aliran Critical Legal Studies}

Pada tahun 1977, di Kota Madison, negara bagian Wisconsin, Amerika Serikat diadakan konferensi yang mengambil tema "Conference on Critical Legal Studies". Konferensi itu kemudian melahirkan sebuah gerakan Critical Legal Studies (CLS). Beberapa tokohnya: Roberto M. Unger, Duncan Kennedy, Karl Klare, Mark Tushnet, Morton Horwitz, dan Jack Balkin. ${ }^{122}$

CLS memandang, hukum dibentuk oleh berbagai faktor nonhukum. Pembentukan hukum mengandaikan interaksi dan negosiasi berbagai kelompok masyarakat. ${ }^{123}$ Hal demikian mengingat dalam pandangan CLS, selain soal pembentukan hukum, pemberlakuannya mengandung pemihakan-pemihakan. Dengan demikian, hukum tidak lagi dilihat sebagai sarana kontrol

119 Safudin, Pengantar Ilmu Hukum, 113-114.

${ }^{120}$ Putro, Kritik Terhadap Paradigma Positivisme Hukum, 93.

121 Ibid.

122 Ibid., 101.

${ }^{123}$ Ibid., 101-102. 
sosial, tetapi juga harus digunakan sebagai sarana rekayasa sosial. ${ }^{124}$

\subsection{Aliran Feminisme Hukum}

Aliran feminisme hukum melihat hukum sejak awal sudah tidak netral, karena dipengaruhi ideologi dominan yang sarat dengan nilai-nilai patriarki. Aliran ini mengkritik hukum yang bersifat phallocentrisme, yaitu suatu pemikiran yang menjadikan laki-laki sebagai tolok ukur dalam memandang suatu hal. ${ }^{125}$ Teori hukum feminisme menawarkan metode hermeneutika dalam melihat hukum maupun yang lebih radikal: dekonstruksi. ${ }^{126}$

Dalam peta feminisme, feminisme "gelombang pertama" memperjuangkan hak pilih bagi peremuan, hak pendidikan, dan hak pekerjaan. Selanjutnya, feminisme "gelombang kedua" memperjuangkan untuk memperkecil perbedaan antara perempuan dengan laki-laki. Istilah lainnya adalah kesetaraan gender. $^{127}$

\subsection{Aliran Hukum Pembangunan}

Aliran hukum pembangunan mulai diperkenalkan oleh Mochtar Kusumaatmadja, pakar hukum internasional, ketika menjadi pembicara dalam Seminar Hukum Nasional pada tahun 1973. Ketika ia menjabat sebagai Menteri Kehakiman, teori hukum yang disebutnya sebagai "Teori Hukum Pembangunan" telah dimasukkan sebagai materi hukum dalam Pelita I (19701975). ${ }^{128}$

Inti ajaran dalam aliran ini adalah: ${ }^{129}$

- Semua masyarakat yang sedang membangun selalu dicirikan oleh perubahan dan hukum berfungsi agar dapat menjamin

124 AZ and Yahyanto, Pengantar Ilmu Hukum (Sejarah, Pengertian, Konsep Hukum, Aliran Hukum, Dan Penafsiran Hukum), 127.

125 Putro, Kritik Terhadap Paradigma Positivisme Hukum, 103.

126 Ibid., 107.

${ }^{127}$ Ibid., 105.

${ }^{128}$ Lihat, Romli Atmasasmita, Teori Hukum Integratif (Rekonstruksi Terhadap Teori Hukum Pembangunan Dan Teori Hukum Progresif) (Yogyakarta: Genta Publishing, 2012), 59-60.

${ }^{129}$ Lihat, Ibid., 65-66. 
bahwa perubahan itu terjadi dengan cara yang teratur melalui peraturan perundang-undangan dan/atau putusan pengadilan.

- Hukum menjadi suatu sarana yang tidak dapat diabaikan dalam proses pembangunan.

- Fungsi hukum dalam masyarakat adalah mempertahankan ketertiban melalui kepastian hukum dan juga hukum (sebagai kaidah sosial) harus dapat mengatur (membantu) proses perubahan dalam masyarakat.

- Hukum yang baik adalah hukum yang sesuai dengan hukum yang hidup (the living law) dalam masyarakat.

- Implementasi fungsi hukum hanya dapat diwujudkan apabila hukum dijalankan oleh suatu kekuasaan yang berjalan dalam rambu-rambu yang ditentukan di dalam hukum tersebut.

\subsection{Aliran Hukum Progresif ${ }^{130}$}

Paradigma positivisme dianggap kurang mampu mewujudkan keadilan substansial, karena cenderung membawa kita menjadi tawanan undang-undang. Pun, pengaruh kolonialisme yang mencengkeram dengan hebatnya. Akibatnya, penegakan hukum di Indonesia masih cenderung legal-formalistik dan penegak hukum menggunakan "kacamata kuda" untuk menegakkan hukum di masyarakat.

Adalah Satjipto Rahardjo yang meletakkan pondasi kerangka konseptual tentang hukum progresif yang kemudian dipopulerkan dan digemakan oleh murid-muridnya (kaum Tjipian) di berbagai tempat dan kesempatan. Guru Besar pada Fakultas Hukum Universitas Diponegoro tersebut dilahirkan di Banyumas, 5 Desember 1930 dan meninggal dunia pada tanggal 8 Januari 2010 (dalam usia 79 tahun).

Istilah "Hukum Progresif" digunakan oleh Satjipto Rahardjo pertama kali dalam artikelnya yang dimuat harian Kompas edisi 15 Juni 2002 dengan judul "Indonesia Butuhkan Penegakan Hukum Progresif". Kata "progesif" sendiri berarti "ke arah kemajuan". Penggunaan kata "progresif" dapat dimaknai

${ }^{130}$ Moch Choirul Rizal, "Membaca Hukum Pidana Progresif," Opini Hukum dan Hak Asasi Manusia 1 (2021): 6-8. 
sebagai pandangan yang humanis dan membebaskan. Hukum progresif menawarkan perspektif, spirit, dan cara baru mengatasi "kelumpuhan hukum" di Indonesia.

Di dalam berbagai referensi yang membahas tentang hukum progresif, paling tidak ada 4 (empat) ciri dan cara berhukum progresif. Pertama, hukum itu untuk manusia. Kelahiran hukum itu untuk harga diri, kebahagiaan, kesejahteraan, dan kemuliaan manusia. Apabila ada masalah dalam hukum, maka hukum itu yang harus ditinjau, bukan manusia yang dipaksakan dalam skema hukum.

Kedua, hukum bukan merupakan institusi mutlak dan final (status quo), karena hukum selalu berada dalam proses untuk terus menjadi (law as a process, law in the making). Hukum akan terus bergerak, berubah, dan mengikuti dinamika kehidupan manusia.

Ketiga, hukum sebagai aspek peraturan dan perilaku. Peraturan akan membangun sistem hukum positif, sedangkan perilaku (manusia) akan menggerakkan peraturan itu. Aspek perilaku berada di atas aspek peraturan.

Keempat, hukum sebagai ajaran pembebasan dari tipe, cara berpikir, asas, dan teori legal-positivistik. Pembebasan tersebut memunculkan kreativitas dan inovasi dengan tetap mengedepankan logika kepatutan sosial, keadilan, dan moralitas. Cara berhukum yang ditunjukkan tidak hanya tekstual, tetapi juga melakukan proses pencarian terhadap makna yang tersembunyi di balik teks yang hidup dalam masyarakat (kontekstual).

\subsection{Aliran Hukum Integratif}

Hukum, menurut Mochtar Kusumaatmadja, merupakan sistem norma. Di sisi yang lain, menurut Satjipto Rahardjo, hukum sebagai sistem perilaku. Menurut aliran hukum integratif yang digagas oleh Romli Atmasasmita, hukum dapat diartikan dan seharusnya juga diartikan sebagai sistem nilai. Dapat disebut, pemikiran dalam aliran hukum integratif merupakan perpaduan 
antara aliran hukum pembangunan dengan hukum progresif dalam konteks Indonesia. ${ }^{131}$

Aliran ini memberikan pencerahan mengenai relevansi dan arti penting hukum dalam kehidupan manusia Indonesia serta mencerminkan bahwa hukum sebagai sistem yang mengatur kehidupan masyarakat tidak dapat dipisahkan dari kultur dan karakter masyarakatnya, letak geografis lingkungannya, sekaligus pandangan hidup masyarakat. Keyakinan aliran ini adalah fungsi dan peranan hukum sebagai sarana pemersatu dan memperkuat solidaritas masyarakat dan birokrasi dalam menghadapi perkembangan dan dinamika kehidupan, baik di dalam lingkup nasional maupun internasional. ${ }^{132}$

131 Atmasasmita, Teori Hukum Integratif (Rekonstruksi Terhadap Teori Hukum Pembangunan Dan Teori Hukum Progresif), 96-97.

132 Ibid., 97-98. 


\section{BAB IX \\ METODE PENAFSIRAN \\ DALAM HUKUM ${ }^{133}$}

Mengutip pendapat Philipus M. Hadjon dan Tatiek Sri Djatmiati, rumusan norma sifatnya abstrak dan konsep pendukungnya dalam banyak hal merupakan konsep terbuka atau konsep yang kabur. Dengan kondisi demikian, langkah selanjutnya adalah melakukan rechtsvinding. Langkah ini dilakukan melalui 2 (dua) teknik. Teknik pertama adalah interpretasi. Teknik kedua adalah konstruksi hukum atau argumentasi hukum. Fungsi rechtsvinding adalah menemukan norma konkrit untuk diterapkan pada fakta hukum terkait. ${ }^{134}$

Pertama, interpretasi, yaitu ada salah satu metode penemuan hukum yang memberi penjelasan yang gamblang mengenai teks undang-undang agar ruang lingkup kaidah dapat ditetapkan sehubungan dengan peristiwa tertentu. Metode intepretasi ini adalah sarana atau alat untuk mengetahui makna undang-undang. Metode penafsiran sejak semula dibagi menjadi 4 (empat), yaitu interpretasi gramatikal, teleologis, sistematis, dan historis. ${ }^{135}$

Kedua, konstruksi hukum. Dapat disebut juga sebagai metode argumentasi. Metode ini digunakan tatkala dalam seorang akademisi atau praktisi hukum menghadapi kekosongan atau ketidaklengkapan undang-undang yang harus diisi atau dilengkapi. Hakim, misalnya, dalam praktik hukum tidak boleh menolak untuk memeriksa dan mengadili suatu kasus dengan alasan tidak ada atau tidak lengkap hukumnya. Dalam kondisi

${ }^{133}$ Bab ini telah terbit sebelumnya dalam Anggit Satriyo Nugroho et al., Modul Pendidikan Dan Pelatihan Kemahiran Hukum (Surabaya: Anggit, Fatah, Priyono (A.F.P.) Law Firm, 2019), 61-71.

${ }^{134}$ Hadjon and Djatmiati, Argumentasi Hukum, 43-44.

135 Mertokusumo, Mengenal Hukum (Suatu Pengantar), 169. 
demikian, akademisi dan praktisi hukum dapat menemukan hukumnya terhadap suatu kasus tertentu dengan metode berpikir analogi, penyempitan hukum, dan a contrario. ${ }^{136}$

\subsection{Interpretasi Gramatikal}

Hukum memerlukan bahasa. Hukum tak mungkin ada tanpa bahasa. Oleh karena itu, bahasa merupakan sarana penting bagi hukum. Peraturan perundang-undangan dituangkan dalam bentuk bahasa tertulis. Putusan pengadilan disusun dalam bahasa tertulis yang logis-sistematis. Untuk mengadakan perjanjian, misalnya, diperlukan bahasa. ${ }^{137}$

Metode interpretasi gramatikal merupakan cara penafsiran atau penjelasan yang paling sederhana untuk mengetahui makna ketentuan undang-undang dengan menguraikannya menurut bahasa, susun kata, atau bunyinya. Menurut Sudikno Mertokusumo, menggunakan interpretasi gramatikal ini sesungguhnya adalah selangkah lebih jauh sedikit dari halnya sekedar "membaca undang-undang". Metode interpretasi ini disebut juga sebagai metode objektif. ${ }^{138}$ Contohnya adalah sebagai berikut: ${ }^{139}$

Penafsiran gramatikal terkait istilah "dipercayakan" seperti yang tercantum dalam Pasal 432 KUHP. Sebuah paket yang "diserahkan" kepada dinas perkeretaapian (PJKA), sedangkan yang berhubungan dengan pengiriman tidak ada lain kecuali dinas itu, berarti juga sama dengan istilah "dipercayakan" sebagaimana tercantum dalam Pasal 432 KUHP.

\subsection{Interpretasi Teleologis}

Interpretasi teleologis adalah metode menafsirkan undang-undang sesuai dengan tujuan pembentukannya. Lebih diperhatikan tujuan dari undang-undang dari pada bunyi kata-kata

136 Ibid., 176.

137 Sudikno Mertokusumo, Penemuan Hukum (Sebuah Pengantar) (Yogyakarta: Liberty, 2009), 57.

138 Mertokusumo, Mengenal Hukum (Suatu Pengantar), 171.

${ }^{139}$ Lihat, Mertokusumo, Penemuan Hukum (Sebuah Pengantar), 58. 
saja. Peraturan perundang-undangan disesuaikan dengan hubungan dan situasi sosial yang baru. Ketentuan undang-undang yang sudah usang digunakan sebagai sarana untuk memecahkan atau menyelesaikan sengketa yang terjadi sekarang. Metode penafsiran ini disebut juga sebagai interpretasi sosiologis. ${ }^{140}$ Contohnya adalah sebagai berikut: ${ }^{141}$

Pada tahun 1921, Hoge Raad harus memutuskan apakah pengambilan energi listrik untuk memilikinya dapat dipandang sebagai pencurian dalam arti 310 WvS (Pasal 362 KUHP). Perdebatan menajam pada kata-kata "barang (eenig goed)". Advocaat Generaal pada Hoge Raad dalam konklusinya berpendapat kata-kata dalam pasal yang mengatur pencurian hanya berkaitan dengan objek-objek jasmaniah dan perundang-undangan pidana bukanlah tempat untuk memakai kata-kata "dalam makna yang dapat diubah-ubah". Namun, Hoge Raad memberikan putusan yang berbeda: ia menunjuk pada tujuan dari adanya $310 \mathrm{WvS}$ (Pasal 362 KUHP), yaitu perlindungan kekayaan orang lain dan menetapkan bahwa energi listrik memperlihatkan ciri-ciri khas dari sebuah objek kekayaan. Dengan demikian, pencurian daya listrik, meskipun tidak berwujud, tetapi dialirkan melalui kawat, adalah "sesuatu barang" yang dapat diambil dengan maksud untuk "memiliknya".

\subsection{Interpretasi Sistematis}

Interpretasi sistematis, yakni metode menafsirkan peraturan perundang-undangan dengan cara menghubungkannya dengan peraturan hukum atau undang-undang lain atau dengan keseluruhan sistem hukum. Menafsirkan undang-undang tidak boleh menyimpang atau keluar dari sistem perundang-undangan atau sistem hukum. Contohnya adalah sebagai berikut: ${ }^{142}$

${ }^{140}$ Ibid., 61.

${ }^{141}$ Lihat, Putro, Kritik Terhadap Paradigma Positivisme Hukum, 156.

${ }^{142}$ Lihat, Mertokusumo, Penemuan Hukum (Sebuah Pengantar), 59. 
Menurut hukum perdata (Pasal 499 KUH Perdata), benda adalah setiap barang dan hak yang dapat dikuasai oleh hak milik, yang berarti dapat menjadi objek pemilikan. Oleh karena tidak mengenal perbudakan, manusia termasuk mayat dalam hukum perdata tidak termasuk dalam objek kepemilikan. Akan tetapi, dalam hukum pidana, mayat adalah milik ahli warisnya dalam batas tertentu, karena ahli warisnya yang menentukan saat atau tempat pemakamannya, boleh tidaknya diadakan otopsi, pencabutan gigi emasnya, pembongkaran makamnya, dan sebagainya (HR 25 Juni 1946, NJ 1946, 503).

\subsection{Interpretasi Historis}

Makna undang-undang dapat dijelaskan atau ditafsirkan juga dengan jalan meneliti sejarah terjadi. Jadi, penafsiran historis merupakan penjelasan menurut terjadinya undang-undang. Pada faktanya, undang-undang itu tidak terjadi begitu saja. Undangundang selalu merupakan reaksi terhadap kebutuhan sosial untuk mengatur yang dapat dijelaskan secara historis. Setiap pengaturan dapat dilihat sebagai satu langkah dalam perkembangan masyarakat. ${ }^{143}$ Contohnya adalah sebagai berikut: ${ }^{144}$

Dari penafsiran sejarah dapat diketahui latar belakang perlunya mengamandemen UUD 1945. Alasan historis, sejak semula dalam sejarahnya UUD 1945 memang didesain oleh para pendiri negara (BPUPKI; PPKI) sebagai UUD yang bersifat sementara, karena dibuat dan ditetapkan dalam suasana ketergesa-gesaan. M. Yamin mengutip statement Ir. Soekarno selaku Ketua PPKI pada tanggal 18 Agustus 1945 untuk menegaskan sifat kesementaraan UUD 1945 sebagai berikut: “... bahwa Undang-Undang Dasar yang dibuat sekarang ini, adalah Undang-Undang Dasar sementara. Kalau boleh saya memakai perkataan:

${ }^{143}$ Mertokusumo, Mengenal Hukum (Suatu Pengantar), 173.

${ }^{144}$ Lihat, Putro, Kritik Terhadap Paradigma Positivisme Hukum, 155. 
ini adalah Undang-Undang Dasar kilat. Nanti kalau kita telah bernegara di dalam suasana yang lebih tenteram, kita tentu akan mengumpulkan kembali Majelis Perwakilan Rakyat yang dapat membuat Undang-Undang Dasar yang lebih lengkap dan lebih sempurna ...."

\subsection{Argumentum per Analogiam}

Kadang-kadang peraturan perundang-undangan terlalu sempit ruang lingkupnya. Dalam hal ini, untuk dapat menerapkan undang-undang pada peristiwanya, hakim misalnya, akan memperluas dengan metode argumentum per analogiam atau analogi. Dengan analogi, maka peristiwa yang serupa, sejenis, atau mirip dengan yang diatur dalam undang-undang diperlakukan sama. Contohnya adalah sebagai berikut: ${ }^{145}$

Pasal 1756 BW menyebut tentang "mata uang (geldspecie)". Apakah uang kertas termasuk di sini?

Dengan jalan analogi, maka "mata uang" menurut

Pasal 1756 BW ditafsirkan termasuk uang kertas.

Di dalam hukum pidana, metode analogi dilarang. Namun, interpretasi ekstensif dibolehkan. Contohnya: dalam kasus pencurian tenaga listrik. Metode analogi dilarang dalam hukum pidana karena bertentangan dengan Pasal 1 ayat (1) KUHP yang mengandung asas legalitas. ${ }^{146}$

\subsection{Penyempitan Hukum}

Kadang-kadang lagi peraturan perundang-undangan itu ruang lingkupnya terlalu umum atau luas. Oleh karenanya, perlu dipersempit untuk dapat diterapkan terhadap suatu peristiwa tertentu. Di sini peraturan yang sifatnya umum diterapkan terhadap peristiwa atau hubungan hukum yang khusus dengan penjelasan atau konstruksi dengan memberi ciri-ciri. Contohnya adalah sebagai berikut: ${ }^{147}$

145 Ibid., 176-178.

146 Selengkapnya lihat, Andi Hamzah, Asas-Asas Hukum Pidana (Jakarta: Rineka Cipta, 2010), 45-56.

${ }^{147}$ Mertokusumo, Penemuan Hukum (Sebuah Pengantar), 172-173. 
Agar "perbuatan melawan hukum (onrechtmatige daad)" sebagaimana diatur dalam Pasal 1365 BW (yang sebelumnya adalah Pasal 1401 BWN) dapat diterapkan pada peristiwa konkrit Cohen lawan Lindebaum, Hoge Raad dalam yurisprudensinya tanggal 31 Januari 1919 (W10365) perbuatan melawan hukum ditafsirkan sempit menjadi: berbuat atau tidak berbuat yang melanggar hak seseorang atau bertentangan dengan kewajiban hukum pelaku atau bertentangan dengan kesusilaan atau sikap berhati-hati yang seyogyanya di dalam masyarakat terhadap seseorang atau benda seseorang. Yurisprudensi Hoge Raad tersebut merupakan yurisprudensi tetap dan sejak itu sampai sekarang diikuti oleh pengadilan di Indonesia. Rumusan perbuatan melawan hukum dalam yurisprudensi Hoge Raad tanggal 31 Januari 1919 tersebut kemudian dituangkan dalam Pasal 162 (6.3.1.1.) 2 BWN baru.

\subsection{Argumentum a Contrario}

Dimungkinkan suatu peristiwa tidak secara khusus diatur oleh undang-undang, tetapi kebalikan dari peristiwa tersebut diatur oleh undang-undang. Cara menemukan hukum dengan pertimbangan bahwa apabila undang-undang menetapkan hal-hal tertentu untuk peristiwa tertentu, maka peraturan itu terbatas pada peristiwa tertentu itu dan untuk peristiwa di luarnya berlaku kebalikannya. Cara demikian terjadi ketika menggunakan metode argumentum a contrario. ${ }^{148}$ Contohnya adalah sebagai berikut: ${ }^{149}$

Apakah yang dimaksud dengan "sebab yang halal" di dalam Pasal 1320 BW? Tidak ada pasal yang menjelaskan apa yang disebut dengan "sebab yang halal". Namun, Pasal 1337 BW mengatur tentang "sebab yang terlarang", yaitu sebab yang

148 Sudikno Mertokusumo, Mengenal Hukum (Sebuah Pengantar), hlm. 180 .

149 Sudikno Mertokusumo, Penemuan Hukum (Sebuah Pengantar), hlm. 70 . 
bertentangan dengan undang-undang, kesusilaan, dan ketertiban umum. Dengan menafsirkan Pasal 1337 BW secara a contrario, maka dapat diketahui bahwa "sebab yang halal" adalah sebab yang tidak bertentangan dengan undang-undang, kesusilaan, dan ketertiban umum. 
66 


\section{BAB X \\ BIDANG-BIDANG STUDI HUKUM}

\subsection{Sosiologi Hukum}

Untuk pertama kalinya, yaitu pada tahun 1882, istilah sosiologi hukum diperkenalkan oleh Anzilotti. ${ }^{150}$ Sosiologi hukum merupakan ilmu yang mempelajari fenomena hukum dari sisi praktik hukum atau hukum sebagaimana dijalankan oleh subjek hukum di tengah-tengah masyarakat. ${ }^{151}$ Sosiologi hukum berusaha memverifikasi pola-pola hukum yang telah dikukuhkan dalam bentuk-bentuk formal tertentu ke dalam tingkah laku orang-orang yang menjalankannya. ${ }^{152}$ Mengingat hal tersebut, sosiologi hukum adalah cabang kajian sosiologi. ${ }^{153}$

Satjipto Rahardjo menyampaikan ada 3 (tiga) karakteristik sosiologi hukum. Pertama, tujuan sosiologi hukum adalah memberikan penjelasan mengapa praktik-praktik hukum terjadi sedemikian adanya. Kedua, studi ini menguji kesahihan empiris dari suatu peraturan atau pernyataan hukum, yaitu bagaimana kenyataannya suatu peraturan hukum tersebut di masyarakat. Ketiga, studi ini menempatkan tingkah laku yang mentaati dan menyimpangi hukum sebagai objek pengamatan yang setaraf guna memberikan penjelasan. ${ }^{154}$

Endrik Safudin menyimpulkan, sosiologi hukum mengkaji hukum sebagai hubungan interaksi antarmanusia dalam praktik-praktik hukum yang terjadi di tengah-tengah masyarakat.

150 Soerjono Soekanto, Mengenal Sosiologi Hukum (Bandung: PT Citra Aditya Bakti, 1993), 13.

${ }^{151}$ Rahardjo, Ilmu Hukum, 325.

152 Ishaq, Dasar-Dasar Ilmu Hukum (Jakarta: Sinar Grafika, 2018), 276.

153 Yesmil Anwar and Adang, Pengantar Sosiologi Hukum (Jakarta:

Penerbit Grasindo, 2015), 114.

${ }^{154}$ Rahardjo, Ilmu Hukum, 326-327. 
Studi ini akan menggambarkan bagaimana hukum telah dijalankan dan bagaimana seharusnya hukum dijalankan dengan mengingat pada sebab-sebab dan faktor-faktor yang mempengaruhinya. ${ }^{155}$

\subsection{Antropologi Hukum}

Anthropologi melihat hukum hanya sebagai aspek kebudayaan, yaitu suatu aspek yang digunakan oleh kekuasaan masyarakat yang teratur dalam mengatur perilaku manusia dan masyarakat. Tujuannya adalah agar tidak terjadi penyimpanganpenyimpangan yang terjadi dari norma-norma sosial yang ditentukan dapat diperbaiki. ${ }^{156}$ Oleh karena itu, karakteristik anthropologi hukum terletak pada sifat pengamatan, penyelidikan, serta pemahamannya secara menyeluruh terhadap kehidupan manusia. ${ }^{157}$

Mengutip pandangan Satjipto Rahardjo, ruang lingkup studi anthropologi hukum, di antaranya, adalah sebagai berikut: ${ }^{158}$

- Bagaimanakah tipe-tipe badan yang menjalankan pengadilan dan perantaraan dalam masyarakat?

- Apakah yang menjadi landasan kekuasaan dari badan-badan itu untuk menjalankan peranannya sebagai penyelesaian sengketa?

- Dalam keadaan tertentu, macam-macam sengketa yang bagaimanakah yang menghendaki penyelesaian melalui pengadilan dan yang manakah menghendaki perundingan?

- Fungsi-fungsi serta efek-efek ekosistemik yang manakah yang bekerja atas suatu proses hukum?

- Prosedur-prosedur manakah yang dipakai untuk masingmasing jenis sengketa pada kondisi-kondisi tertentu?

- Bagaimanakah keputusan itu dijalankan?

155 Safudin, Pengantar Ilmu Hukum, 208.

156 Hilman Hadikusumah, Antropologi Hukum Indonesia (Bandung: Alumni, 1986), 1.

${ }^{157}$ Rahardjo, Ilmu Hukum, 334.

158 Ibid., 339-340. 
- Bagaimanakah hukum berubah?

Dalam beberapa referensi, anthropologi hukum mempunyai persamaan dengan sosiologi hukum. Keduanya dimaksudkan untuk mengerti dan kemudian dapat menjelaskan fenomena hukum, sehingga tidak memakai peraturan-peraturan hukum yang konkrit bagi mengarahkan tingkah laku manusia. Dengan demikian, keduanya akan bertemu dalam pandangan dan pendekatan yang sama, yaitu tidak dapat dilepaskan dari keseluruhan proses-proses di dalam masyarakat. ${ }^{159}$

\subsection{Perbandingan Hukum}

Perbandingan hukum mempunyai arti sebagai studi untuk membanding-bandingkan sistem hukum positif antara bangsa yang satu dengan bangsa yang lainnya. ${ }^{160}$ Dengan demikian, ruang lingkup perbandingan hukum adalah memperbandingkan sistem hukum dari satu atau beberapa masyarakat yang berkaitan dengan isi kaidah-kaidah, dasar kemasyarakatannya, serta sebabsebabnya, sehingga didapat persamaan dan juga perbedaannya. ${ }^{161}$ berikut: ${ }^{162}$

Tujuan adanya studi ini, di antaranya, adalah sebagai

- Menunjukkan perbedaan dan persamaan yang ada di antara sistem hukum atau bidang-bidang hukum yang dipelajari.

- Menjelaskan mengapa terjadi persamaan atau perbedaan yang demikian itu dan faktor-faktor apa yang menyebabkannya.

- Memberikan penilaian terhadap masing-masing sistem yang digunakan.

- Memikirkan kemungkinan-kemungkinan apa yang bisa ditarik sebagai kelanjutan dari hasil-hasil studi perbandingan yang telah dilakukan.

- Merumuskan kecenderungan-kecenderugan yang umum pada perkembangan hukum, termasuk di dalamnya irama dan

\footnotetext{
${ }^{159}$ Ibid., 333.

${ }^{160}$ Ibid., 348.

${ }^{161}$ Ishaq, Dasar-Dasar Ilmu Hukum, 283.

162 Rahardjo, Ilmu Hukum, 348-349.
} 
keteraturan yang dapat dilihat pada perkembangan hukum tersebut.

- Salah satu segi yang penting dari perbandingan ini adalah kemungkinan untuk menemukan asas-asas umum yang didapat sebagai hasil dari pelacakan yang dilakukan dengan cara membandingkan tersebut.

Dapat dikatakan bahwa studi ini akan bermanfaat bagi penyingkapan latar belakang terjadinya ketentuan hukum tertentu untuk masalah yang sama dari suatu negara atau lebih. Di samping itu, menurut Endrik Safudin, studi ini juga akan menyingkap terjadinya ketentuan hukum tertentu untuk masalah yang sama dari suatu periode pemerintahan dengan periode pemerintahan yang lain dalam satu negara. ${ }^{163}$

\subsection{Sejarah Hukum}

Tidak dapat dinafikan bahwa hukum yang berlaku saat ini dibentuk melalui proses-proses yang berlangsung pada masa lampau. Fakta demikian yang menjadikan studi terkait sejarah hukum menjadi penting. Dengan kata lain, studi ini mempelajari, misalnya, bagaimana proses-proses hukum yang dibentuk pada masa lalu dan berlaku hingga saat ini.

Menurut Endrik Safudin, sejarah hukum sesungguhnya hendak memberikan arti yang penting terhadap pertelaahan sejumlah peristiwa yuridis dari zaman dahulu yang disusun secara kronologis. Dengan adanya studi semacam ini, seorang yuris akan dapat mengenali dan memahami secara sistematik proses-proses terbentuk hukum, tak terkecuali mengenai faktor-faktor penyebabnya. ${ }^{164}$

Satjipto Rahardjo menyebutkan beberapa pertanyaan yang dapat dijawab sehubungan dengan studi sejarah hukum, yaitu sebagai berikut: ${ }^{165}$

163 Safudin, Pengantar Ilmu Hukum, 212.

164 Ibid., 208-209.

165 Rahardjo, Ilmu Hukum, 351. 
- Faktor-faktor apa sajakah yang mempengaruhi terbentuknya suatu lembaga hukum tertentu dan bagaimana jalannya proses pembentukan itu?

- Faktor apakah yang dominan pengaruhnya dalam proses pembentukan suatu lembaga hukum tertentu dan apa sebabnya?

- Bagaimanakah interaksi antara pengaruh-pengaruh yang datang dari luar dengan kekuatan perkembangan dari dalam masyarakat sendiri?

- Bagaimanakah jalannya proses adaptasi terhadap lembagalembaga yang diambil dari sistem hukum asing?

- Apakah suatu lembaga hukum tertentu selalu menjalankan fungsi yang sama?

- Faktor-faktor apakah yang menyebabkan hapusnya atau tidak digunakannya lagi suatu lembaga hukum tertentu?

- Dapatkah dirumuskan suatu pola perkembangan yang umum yang dijalani oleh lembaga-lembaga hukum dari suatu sistem hukum tertentu?

\subsection{Psikologi Hukum}

Dalam perkembangan era hukum modern, hukum telah memasuki bidang yang dapat menggarap tingkah laku manusia, misalnya, dengan menggunakan psikologi. ${ }^{166}$ Dalam hal dikaitkan dengan hukum, psikologi hukum merupakan suatu cabang ilmu pengetahuan yang mempelajari hukum sebagai suatu perwujudan daripada perkembangan jiwa manusia. ${ }^{167}$

Menurut Soedjono Dirdjosisworo, ruang lingkup psikologi hukum meliputi segi psikologi tentang terbentuknya norma atau kaidah hukum, kepatuhan atau ketaatan terhadap kaidah hukum, perilaku menyimpang, dan psikologi dalam hukum pidana dan pengawasan perilaku. ${ }^{168}$ Dengan demikian,

166 Ibid., 353.

167 Purnadi Purbacaraka and Soerjono Soekanto, Perihal Kaedah Hukum (Bandung: Alumni, 1982), 10-11.

168 Soedjono Dirdjosisworo, Pengantar Tentang Psikologi Hukum (Bandung: Alumni, 1983), 40. 
paling tidak, di dalam studi ini akan mempelajari perikelakuan hukum dari seseorang, baik yang normal (yang menyebabkan seseorang mematuhi hukum) dan abnormal (yang menyebabkan seseorang melanggar hukum). ${ }^{169}$

Mengutip dari pendapat Soedjono, ruang lingkup psikologi hukum meliputi: (1) segi psikologi tentang terbentuknya norma atau kaidah hukum; (2) kepatuhan atau ketaatan terhadap kaidah hukum; (3) perilaku menyimpang; dan (4) psikologi dalam hukum pidana dan pengawasan perilaku. Di samping itu, Soerjono Soekanto juga membagi ruang lingkup psikologi hukum menjadi: (1) dasar-dasar kejiwaan dan fungsi pelanggaran terhadap kaidah hukum; (2) dasar-dasar kejiwaan dan fungsi pola-pola penyelesaian pelanggaran kaidah hukum; dan (3) akibat-akibat dari pola penyelesaian sengketa tertentu. ${ }^{170}$

\subsection{Filsafat Hukum}

Filsafat hukum adalah ilmu pengetahuan yang mempersoalkan pertanyaan-pertanyaan yang mendasar dari hukum $^{171}$, yang tidak terjawab oleh ilmu hukum ${ }^{172}$. Jumlah pertanyaan itu tak terhingga banyaknya. ${ }^{173}$

Filsafat hukum merupakan refleksi tentang hukum yang mempermasalahkan hukum dari pelbagai pertanyaan yang mendasar, misalnya: (1) Apakah hakikat hukum itu?; (2) Apa dasar-dasar mengikatnya hukum?; (3) Mengapa hukum berlaku umum?; atau Bagaimana hubungan hukum dengan kekuasaan, moral, dan keadilan? ${ }^{174}$ Mengingat filsafat hukum merupakan ruang lingkup dalam studi hukum, ia akan melakukan penyidikan yang lebih mendalam untuk mengetahui bagian dalam dari hukum itu sendiri. ${ }^{175}$

${ }^{169}$ Ishaq, Dasar-Dasar Ilmu Hukum, 295.

${ }^{170}$ Lihat, Safudin, Pengantar Ilmu Hukum, 215.

${ }^{171}$ Rahardjo, Ilmu Hukum, 358.

172 Syarifin, Pengantar Ilmu Hukum, 77-78.

173 L.J. van Apeldoorn, Inleiding Tot de Studie van Het Nederlandse Recht (Jakarta: Pradnya Paramita, 2001), 428.

${ }^{174}$ Machmudin, Pengantar Ilmu Hukum (Sebuah Sketsa), 5.

175 Safudin, Pengantar Ilmu Hukum, 204. 
Filsafat hukum berusaha mengungkapkan hakikat hukum dengan menemukan landasan terdalam dari keberadaan hukum sejauh yang mampu dijangkau akal budi manusia. Objek formalnya adalah hukum dipandang dari dua pertanyaan fundamental yang saling berkaitan (dwitunggal pertanyaan inti). Pertanyaan tersebut sudah tergantung masalah tujuan hukum, hubungan hukum dan kekuasaan, serta hubungan hukum dan moral. ${ }^{176}$

Ada 3 (tiga) manfaat adanya filsafat hukum. Pertama, membangun argumentasi oleh para pihak yang mengadakan hubungan hukum atau bersengketa. Kedua, dasar pemikiran pengambilan keputusan oleh penyelenggara negara, yaitu eksekutif, legislatif, dan yudisial. Ketiga, landasan membangun konsep hukum. ${ }^{177}$

\subsection{Politik Hukum}

Ilmu hukum cenderung kaku dan kering. Ilmu hukum diarahkan pada cara untuk mencapai tujuan. Di sisi yang lain, filsafat hukum sifatnya spekulatif dan abstrak. Filsafat hukum diarahkan untuk melihat tujuan yang diinginkan. ${ }^{178}$ Proses interplay antara "cara untuk mencapai tujuan" dan "melihat tujuan yang diinginkan" itulah kemudian yang melahirkan politik hukum.

Politik hukum dalam disiplin hukum bergerak pada tataran etik dan teknik kegiatan pembentukan dan penemuan hukum. ${ }^{179}$ Politik hukum diarahkan untuk melihat sejauh mana hukum yang dibentuk memiliki nilai guna dan gerak dalam proses transformasi masyarakat yang diinginkan. Politik hukum berbicara pada tataran empiris-fungsional dengan menggunakan metode teleologis-konstruktif. ${ }^{180}$

176 Imam Syaukani and A. Ahsin Thohari, Dasar-Dasar Politik Hukum (Jakarta: PT RajaGrafindo Persada, 2004), 38-39.

${ }_{177}$ Marzuki, Pengantar Ilmu Hukum, 26.

178 Syaukani and Thohari, Dasar-Dasar Politik Hukum, 40.

179 Soerjono Soekanto and R. Otje Salman, Disiplin Hukum Dan Disiplin Sosial (Jakarta: Rajawali Press, 1988), 175-176.

180 Purnadi Purbacaraka and M. Chidir Ali, Disiplin Hukum (Bandung: PT Citra Aditya Bakti, 1990), 1. 
Secara etimologis, politik hukum secara singkat berarti kebijaksanaan hukum. ${ }^{181}$ Sementara itu, secara terminologis, sesuai dengan beberapa literatur yang ada, politik hukum adalah strategi yang sistematis, terinci, dan mendasar dari penyelenggara negara untuk membentuk peraturan perundang-undangan yang akan berlaku pada masa mendatang sekaligus mengevaluasi yang sedang berlaku pada masa sekarang yang bersumber dari nilainilai yang berlaku di masyarakat untuk mencapai tujuan negara yang dicita-citakan.

Menurut Imam Syaukani dan A. Ahsin Thohari, ruang lingkup atau wilayah kajian politik hukum adalah: (1) proses penggalian nilai-nilai dan aspirasi yang berkembang dalam masyarakat oleh penyelenggara negara yang berwenang merumuskan politik hukum; (2) proses perdebatan dan perumusan nilai-nilai dan aspirasi tersebut ke dalam bentuk sebuah rancangan peraturan perundang-undangan oleh penyelenggara negara yang berwenang merumuskan politik hukum; (3) penyelenggara negara yang berwenang merumuskan dan menetapkan politik hukum; (4) peraturan perundangundangan yang memuat politik hukum; (5) faktor-faktor yang mempengaruhi dan menentukan suatu politik hukum, baik yang akan, sedang, dan telah ditetapkan; dan (6) pelaksanaan dari peraturan perundang-undangan yang merupakan implementasi dari politik hukum suatu negara. ${ }^{182}$

Dengan adanya politik hukum, penyelenggara negara mampu menggali nilai-nilai dan aspirasi-aspirasi yang berkembang dalam masyarakat untuk membentuk maupun mengevaluasi peraturan perundang-undangan. Dengan keadaan demikian, masyarakat diharapkan mampu untuk memberikan kritik maupun saran kepada penyelenggara negara.

Dengan adanya politik hukum, penyelenggara negara mampu membentuk dan mengevaluasi peraturan perundangundangan yang diserap dari penggalian terhadap nilai-nilai dan aspirasi-aspirasi yang berkembang di tengah-tengah masyarakat. Dengan keadaan demikian, peraturan perundang-undangan yang

${ }^{181}$ Syaukani and Thohari, Dasar-Dasar Politik Hukum, 25.

182 Ibid., 51-52. 
dibentuk dan dievaluasi diharapkan selaras dengan eksistensi masyarakat. 


\section{DAFTAR PUSTAKA}

AK and Partners. "Macam-Macam Sistem Hukum Di Dunia." Accessed September 10, 2021. https://kantorhukumakp.com/berita-macam-macam-sistem-hukum-di-dunia.

Ali, Achmad. Menguak Tabir Hukum. Bogor: Ghalia Indonesia, 2011.

Anwar, Yesmil, and Adang. Pengantar Sosiologi Hukum. Jakarta: Penerbit Grasindo, 2015.

Apeldoorn, L.J. van. Inleiding Tot de Studie van Het Nederlandse Recht. Jakarta: Pradnya Paramita, 2001.

Asyhadie, Zaeni, and Arief Rahman. Pengantar Ilmu Hukum. Jakarta: PT RajaGrafindo Persada, 2013.

Atmasasmita, Romli. Teori Hukum Integratif (Rekonstruksi Terhadap Teori Hukum Pembangunan Dan Teori Hukum Progresif). Yogyakarta: Genta Publishing, 2012.

AZ, Lukman Santoso, and Yahyanto. Pengantar Ilmu Hukum (Sejarah, Pengertian, Konsep Hukum, Aliran Hukum, Dan Penafsiran Hukum). Malang: Setara Press, 2016.

Baro, Rachmad. Teori Hukum. Makassar: Lephaer Unkhair dan Intan Cendekia, 2005.

Budiarjo, Miriam. Dasar-Dasar Ilmu Politik. Jakarta: PT Gramedia Pustaka Utama, 2008.

Daliyo, J.B. Pengantar Hukum Indonesia. Jakarta: PT Prenhallindo, 2001.

Departemen Pendidikan Nasional. Kamus Besar Bahasa Indonesia. Jakarta: Balai Pustaka, 2001.

Dirdjosisworo, Soedjono. Pengantar Tentang Psikologi Hukum. Bandung: Alumni, 1983. 
Hadikusumah, Hilman. Antropologi Hukum Indonesia. Bandung: Alumni, 1986.

Hadjon, Philipus M., and Tatiek Sri Djatmiati. Argumentasi Hukum. Yogyakarta: Gadjah Mada University Press, 2017.

Hamzah, Andi. Asas-Asas Hukum Pidana. Jakarta: Rineka Cipta, 2010.

Hanoraga, Tony. "Dialektika Hubungan Hukum Dan Kekuasaan.” Jurnal Sosial Humaniora 1, no. 1 (2008): 43-65.

Huijbers, Theo. Filsafat Hukum Dalam Lintasan Sejarah. Yogyakarta: Kanisius, 2008.

Ishaq. Dasar-Dasar Ilmu Hukum. Jakarta: Sinar Grafika, 2018.

Istanto, Sugeng. Hukum Internasional. Yogyakarta: Universitas Atma Jaya, 2014.

Johanes, Mardimin. Jangan Tangisi Tradisi. Yogyakarta: Kanisius, 1994.

Kansil, C.S.T. Pengantar Ilmu Hukum Dan Tata Hukum Indonesia. Bogor: Balai Pustaka, 1986.

Kansil, C.S.T., and Christine S.T. Kansil. Pengantar Ilmu Hukum Indonesia. Jakarta: Rineka Cipta, 2011.

Kartohadiprodjo, Sudiman. Pengantar Tata Hukum Di Indonesia, 1956.

Kusumaatmadja, Mochtar. Fungsi Dan Perkembangan Hukum Dalam Pembangunan Nasional. Bandung: Bina Cipta, 1970.

Machmudin, Dudu Duswara. Pengantar Ilmu Hukum (Sebuah Sketsa). Bandung: PT Refika Aditama, 2001.

Marwan. Pengantar Ilmu Hukum. Jakarta: Ghalia Indonesia, 2004.

Marzuki, Peter Mahmud. Pengantar Ilmu Hukum. Jakarta: Kencana, 2018. 
Mertokusumo, Sudikno. Mengenal Hukum (Suatu Pengantar). Yogyakarta: Liberty, 2008.

- Penemuan Hukum (Sebuah Pengantar). Yogyakarta: Liberty, 2009.

Moleong, Lexy J. Metodologi Penelitian Kualitatif. Bandung: Alumni, 2007.

Monteiro, Josef Mario. Konsep Dasar Ilmu Hukum. Malang: Setara Press, 2017.

Mustamu, Julista. "Pertanggungjawaban Hukum Pemerintah (Kajian Tentang Ruang Lingkup Dan Hubungan Dengan Diskresi)." SASI: Jurnal Ilmiah Fakultas Hukum Universitas Pattimura Ambon 20, no. 2 (2014): 21-27.

Nilla, Dzawi Kafa. "Mengenal Sumber Hukum: Sejarah Dan Jenisnya." Heylaw Edu. Last modified 2021. Accessed September 10, 2021. https://heylawedu.id/blog/mengenalsumber-hukum-sejarah-dan-jenisnya.

Nugroho, Anggit Satriyo, Abdul Fatah, Eko Priyono, Sugianto, Istiqfar Ade Noordiansyah, Moch Choirul Rizal, Abdul Roup, and Dwi Nurgianto. Modul Pendidikan Dan Pelatihan Kemahiran Hukum. Surabaya: Anggit, Fatah, Priyono (A.F.P.) Law Firm, 2019.

Purbacaraka, Purnadi, and M. Chidir Ali. Disiplin Hukum. Bandung: PT Citra Aditya Bakti, 1990.

Purbacaraka, Purnadi, and Soerjono Soekanto. Perihal Kaedah Hukum. Bandung: Alumni, 1982.

Putro, Widodo Dwi. Kritik Terhadap Paradigma Positivisme Hukum. Yogyakarta: Genta Publishing, 2011.

Rahardjo, Satjipto. Ilmu Hukum. Bandung: PT Citra Aditya Bakti, 2000.

Rizal, Moch Choirul. Buku Ajar Hukum Pidana. Kediri: Lembaga Studi Hukum Pidana, 2021.

. Diktat Hukum Acara Pidana. Kediri: Fakultas Syariah IAIN Kediri, 2021. 
_. "Membaca Hukum Pidana Progresif." Opini Hukum dan Hak Asasi Manusia 1 (2021): 5-10.

Safudin, Endrik. Pengantar Ilmu Hukum. Malang: Setara Press, 2020.

Soekanto, Soerjono. Mengenal Sosiologi Hukum. Bandung: PT Citra Aditya Bakti, 1993.

Soekanto, Soerjono, and R. Otje Salman. Disiplin Hukum Dan Disiplin Sosial. Jakarta: Rajawali Press, 1988.

Soemantri, Sri. Ketatanegaraan Indonesia Dalam Sistem Politik Indonesia. Jakarta: Pustaka Sinar Harapan, 1993.

Soeroso, R. Pengantar Ilmu Hukum. Jakarta: Sinar Grafika, 2011.

Sudirdja, Rudi Pradisetia. "Mencari Definisi Hukum Menurut Para Ahli Dan Membuat Kesimpulan." Last modified 2010. Accessed September 6, 2021. http://www.rudipradisetia.com/2010/09/mencari-definisihukum-menurut-para_14.html.

Syarifin, Pipin. Pengantar Ilmu Hukum. Bandung: Pustaka Setia, 1999.

Syaukani, Imam, and A. Ahsin Thohari. Dasar-Dasar Politik Hukum. Jakarta: PT RajaGrafindo Persada, 2004.

Tanya, Bernard L., Yoan N. Simanjuntak, and Markus Y. Hage. Teori Hukum: Strategi Tertib Manusia Lintas Ruang Dan Generasi. Yogyakarta: Genta Publishing, 2010.

Thamrin, Husni. Orang Melayu: Agama, Kekerabatan, Dan Perilaku Ekonomi. Kampar: Lembaga Penelitian dan Pengabdian kepada Masyarakat Mutu Universitas Islam Negeri Sultan Syarif Kasim, 2009.

Tutik, Titik Triwulan. Pengantar Ilmu Hukum. Jakarta: Prestasi Pustaka Publisher, 2006.

Wignjosoebroto, Soetandyo. Hukum: Konsep Dan Metode. Malang: Setara Press, 2013. 


\section{TENTANG PENYUSUN}

Ach. Khiarul Waro Wardani, lahir di Madiun, 31 Mei 1990. Penyusun adalah Dosen pada Fakultas Syariah IAIN Kediri. Di dalam penyusunan diktat ini, pengampu mata kuliah "Pengantar Ilmu Hukum" pada Program Studi Hukum Keluarga Islam ini menyusun: (1) Bab II: Pengertian, Fungsi, dan Tujuan Hukum; (2) Bab III: Hukum sebagai Institusi Sosial; dan (3) Bab IV: Beberapa Konsep Dasar dalam Hukum. Untuk keperluan korespondensi, penyusun dapat dihubungi melalui e-mail:wardaniahmad25@gmail.com.

Hutrin Kamil, lahir di Kendari, 17 Agustus 1989. Penyusun adalah Dosen pada Fakultas Syariah IAIN Kediri. Di dalam penyusunan diktat ini, pengampu mata kuliah "Pengantar Ilmu Hukum" pada Program Studi Hukum Ekonomi Syariah ini menyusun: (1) Bab V: Beberapa Asas dalam Hukum; (2) Bab VI: Berbagai Sistem Hukum di Dunia; dan (3) Bab VII: SumberSumber Hukum. Untuk keperluan korespondensi, penyusun dapat dihubungi melalui e-mail: hutrinkamil@iainkediri.ac.id.

Moch Choirul Rizal, lahir di Kota Surabaya, 17 Oktober 1990. Penyusun adalah Dosen pada Fakultas Syariah IAIN Kediri. Di dalam penyusunan diktat ini, pengampu mata kuliah "Pengantar Ilmu Hukum" pada Program Studi Hukum Tata Negara ini menyusun: (1) Bab I: Karakter Ilmu Hukum; (2) Bab VIII: Beberapa Aliran dalam Hukum; (3) Bab IX: Metode Penafsiran dalam Hukum; dan (4) Bab X: Bidang-Bidang Studi Hukum. Untuk keperluan korespondensi, penyusun dapat dihubungi melalui $e$ mail: rizal@iainkediri.ac.id. Informasi lainnya mengenai karya-karya penyusun, silakan mengunjungi blog: www.mochchoirulrizal.com. 

Diktat ini kami maksudkan untuk menambah referensi bagi mahasiswa pada Fakultas Syariah Institut Agama Islam Negeri (IAIN) Kediri yang mengambil mata kuliah "Pengantar Ilmu Hukum". Penyusunan diktat ini kami selaraskan dengan rencana pembelajaran semester dalam mata kuliah yang dimaksud.

Diktat ini kami susun berdasarkan pada berbagai referensi terkait dasar-dasar ilmu hukum yang terbit sebelumnya. Untuk mempermudah pembacaan, diktat ini tersusun atas 10 (sepuluh) bab: (1) Bab I: Karakteristik Ilmu Hukum; (2) Bab II: Pengertian, Fungsi, dan Tujuan Hukum; (3) Bab III: Hukum sebagai Institusi Sosial; (4) Bab IV: Beberapa Konsep Dasar dalam Hukum; (5) Bab V: Beberapa Asas dalam Hukum; (6) Bab VI: Berbagai Sistem Hukum di Dunia; (7) Bab VII: Sumber-Sumber Hukum; (8) Bab VIII: Beberapa Aliran dalam Hukum; (9) Bab IX: Metode Penafsiran dalam Hukum; dan (10) Bab X: Bidang-Bidang Studi Hukum.

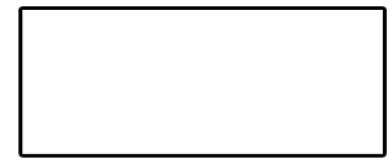

